\title{
Tarp industrinio ir kritinio dizaino. Dizainerio požiūris
}

\section{Vytautas Gečas}

Vilniaus dailès akademija

Maironio g. 6, LT-01124 Vilnius

vgecass@gmail.com

— Tekste nagrinejjamas industrinis ir kritinis dizainas - jų sankirtos ir skirties taškai. Šios dvi dizaino sritys iš esmès aprẻpia tą patị daiktu kūrimo kontekstą, bet atlieka jame skirtingus vaidmenis. Viena kitą papildydamos šiuolaikiniame dizaine jos tampa skirtingą vertybini suvokimą reprezentuojančiomis pusėmis. Dėl taikomų skirtingų dizaino metodų jos neretai lieka savo specifinèse praktikose. Kritinio dizaino kūrybiniai metodai dažnai koreliuoja su šiuolaikinio meno lauku, bet remiantis tradiciniu dizainu jo nauji metodai tampa sunkiai perskaitomi. Tuo tarpu industrinio dizaino praktika dažniausiai atliepia komercinės rinkos arba gamybinès bazės poreikius, bet nebūtinai dizaino ar vartotojo. Straipsnyje analizuojama, kaip šios praktikos formavosi istoriškai, kuo jos skiriasi ir kaip yra susijusios viena su kita.

Reikšminiai žodžiai: kritinis dizainas, industrinis dizainas, šiuolaikinis dizainas, funkcija, vartotojiškumas. 


\section{Dizainas kaip profesija}

Šis straipsnis yra platesnio žmogaus ir daiktų santykių tyrimo dalis. Paskatintas trinties tarp dviejų dizaino sričiu - industrinio ir kritinio, savo tyrimu siekiu išryškinti dualistinę šiuolaikinio dizaino kūrèjo situaciją ir jos ittaką daiktų kūrimo procesui.

Didejjanti dizaino profesijos įtaka žmonių gyvenimui plečia dizainerio atsakomybių lauką. Masinė daiktų gamyba palieka globalų fizini pėdsaką ir yra svarbi tvarumo diskurse. O plačiai ir lengvai pasiekiamas daiktų dizainas yra tapęs neatsiejama vartotojiškos kultūros ir individo kasdienybès dalimi. Tai skatina permąstyti daiktų daromą įtaką ir kuriamą vertę. Besikeičiantis dizaino kūrejjo (autoriaus) vaidmuo verčia kvestionuoti tradicinį šiuolaikinio dizainerio vaidmens ir kūrybos proceso suvokimą.

Kita vertus, industrinio ir kritinio dizaino praktikų priešprieša ir dizainerio profesijos dvilypumas leidžia įvardyti dizaino metodus, turinčius ittakos daiktus suvokti skirtingai, ir taikyti juos kūrybinëje praktikoje atitinkamoje šiuolaikinio dizaino srityje.

Daiktų dizaino profesija yra suvokiama ir traktuojama ịvairiai, priklausomai nuo istorinių, technologinių ar vertybinių aplinkybių. Tai taip pat lemia pozicija, iš kurios yra konstruojama ir suvokiama daikto kuriama vertè: autoriaus dizainerio, vadybininko, gamintojo, vartotojo, galerininko, kolekcininko, žiūrovo. Ir žmonès, ir daiktai atlieka ịvairius vaidmenis, veikia ịvairiose situacijose. Daiktai tampa mūsų kasdienybès liudininkais, ịpročiu formuotojais ir choreografais. Ir pats žmogus savo ịpročiais daro įtaką, kaip ir kokie daiktai turi būti kuriami, o daiktai formuoja mus ir mūsų elgesị. Tai du persipinantys scenarijai, kurie nuolat papildo vienas kitą. Dizainas, kaip profesija, tampa mūsų kasdienybės stebètoju ir kūrèju.

Pasyvų ir aktyvų dizaino profesijos vaidmenis kasdienybėje patvirtina ir tai, kad kiekvieną akimirką mes esame dizaino ir daiktų apsuptyje1. Daiktai tampa mūsų kūnų tąsa ir ịrankiais pažinti bei suvokti aplinką. Irankio savybès lemia, kad aplinka suvokiama ịvairiai. Medžiagiškumas, ergonomika, estetika tampa daiktiškosiomis savybėmis, formuojančiomis

1 „Gimimas - tai procesas, skelbiantis gyvenimo pradžią, kuris bus nuolatos lydimas dizaino objektų iš esmès iki paskutinès jo akimirkos. Kada paskutinị kartą maudètės nuogi natūraliame vandens telkinyje (be kvepalų, makiažo, papuošalų, dezodoranto, medicininių, stomatologinių ar kosmetinių implantų)? Kada paskutinị kartą buvote pasivaikščioti nuogi po laukinę gamtą? Žmogaus kasdienybė yra užpildyta dizainu, kaip oras yra užpildytas mikroorganizmų." Bruce M. Tharp ir Stephanie M. Tharp, Discursive Design: Critical, Speculative, and Alternative Things (Cambridge, Massachusetts: MIT press, 2019), 6. 
daikto fizinę išraišką ir jo suvokimą. Laikmečio kultūrinis kontekstas kuria funkcinę, ekonominę ir simbolinę daikto vertes. Skirtinga fizinè ir kultūrinè daikto itaka žmogui, jo gyvenimui tampa kaitos ir virsmo katalizatoriumi, sietinu su visuomenės progresu. Daiktai tampa objektais, užtikrinančiais mūsų komfortą ir padedančiais ìveikti fizinius iššūkius. Nuo kèdès iki traukinio lokomotyvo, iki šakutès - daiktai tampa ịrankiais, kurie palengvina mūsų gyvenimus, padidina mūsų pačių ir mūsų aplinkos potencialą.

Toks visavertis profesijos apibūdinimas mane, kaip dizaino praktiką, skatina ne tik analizuoti savo veikimo lauką, bet ir ịsivertinti atsakomybę. Tiesa, tai gali skambèti kaip abstrakti ir bendrinè tiesa, bandanti ịprasminti dizainą bendražmogiškų vertybiu kontekste: kaip jis formavo mus istorinèje ir kultūrinėje visuomenès raidoje, koks svarbus yra mūsų kasdienybejje ir kaip be jo būtu sudètinga šiandien gyventi. Tai turbūt tinka bet kuriai kitai profesijai - medicinai, teisei, tiksliesiems mokslams. Kiekvienas savo profesijos puoselètojas sureikšmina savo darbo prasmę, formuodamas jai kuo aukštesnius tikslus. Bet ką toks dizaino profesijos suvokimas reiškia, lemia daiktų kontekste? Bendrinis specialybės aprašas - tai teorinio diskurso pradžia. Neatsitiktinai dizaino teorinių veikalu ịvadai tuo ir pradedami. Bet abejoju, ar tai yra žinios, kurios aprėpia visus vaidmenis, apsprendžiančius dizaino objekto vertinimą, vartojimą, kūrimą. Manau, kad visi dizaino srities vaidmenys (autorius, gamintojas, vartotojas ir t. t. ) yra lygiaverčiai daikto gyvenime. Industrinio dizaino praktika rodo, kad bendrinès žinios nebūtinai reikalingos, kuriant daiktą. Pakanka remtis fizinių savybių išmanymu ir instrumentine praktika, kitaip tariant, atlikti savo darbą pagal savo specialybę - kurti naują daiktą, analizuojant panašų anksčiau igyvendintą dizaino kūrinị. Turbūt todèl dizaino bakalauro studijų metu ịprastai yra keliamas klausimas - kaip padaryti daiktą, bet ne kodèl?²

Aptariamo pobūdžio dizaino traktuotè, žinoma, gali pristatyti ir konkretų dizaino kūrinį ar daiktą. Tačiau taip abstrakčiai ir net kiek pretenzingai vertinant daikto ịtakos žmogui mastą, galiausiai liekama su įvardyta bendrine tiesa, iš esmès taikytina bet kuriam daiktui (taip pat ir blogo dizaino pavyzdžiui). Abstrakčiai ịvardijama arba, kitaip sakant, neịvardijama daikto vertè skatina permąstyti, konkretizuoti galimą daikto poveikio skalę.

2 Vytautas Michelkevičius, Meninio tyrimo suvesti, žinojimo kontūras (Vilnius: Vilniaus dailès akademijos leidykla, 2016), 15-16. 
Konstatuojamoji globali dizaino įtaka gali susitraukti ir iki paties mažiausio mastelio - daikto santykio su žmogumi „vienas prieš vieną“. Nuo abstraktaus globalaus mastelio iki labai artimo, intymaus ir tiesiogiai veikiančio žmogų - toks situacijos paradoksalumas mane žavi, ịprasmina dizaino praktiką ir tuo pačiu rodo, kad nagrinėjama problematika yra kompleksinè ir nevienalytè.

Industrinis dizainas išlieka pagrindine praktika, formuojančia, kaip ir kokie daiktai yra kuriami. Tai susiklostè istoriškai, kai standartizuoti procesai leido supaprastinti medžiagų apdirbimo ir gamybos procesus. Kas anksčiau buvo atliekama rankomis, tapo standartizuota gamyba, pagreitinusia darbą ir padidinusia produkcijos kiekius. Atpigo ir paties objekto kaina, padidèjo paprastų buitinių daiktų pasiekiamumas žmonėms. Kalbu apie industrinę revoliuciją, kurios metu iš esmès pasikeitė mūsų buitis ir ịpročiai, taip pat ir gyvenimo kaitos pagreitis. Iki industrinès revoliucijos bent 600 metų (1220-1820) paprasto žmogaus dienotvarkẻ ir gyvenimo standartai nelabai kito ${ }^{3}$. Jis buvo priklausomas nuo gamtos dėsnių ir metų laikų kaitos. Naujų fabrikų atsiradimas masiškai perkraustė kaimo gyventojus į miestus ir emancipavo juos nuo būtinybès patiems rūpintis visu savo namų ūkiu ir maistu. Kuriami daiktai tapo svertu, lengvinančiu visuomenės kasdienybę, keičiančiu (spartinančiu) fizinius darbus. Kartu kito ir žmonių ịpročiai bei poreikiai, išsilaisvinę iš agrarinių fizinių darbų, apsirūpinę buitiniais daiktais, jie galèjo susikaupti veiklai, kuriančiai didesnę pridètinę vertę visai visuomenei. Išvada - apsirūpinimas daiktais tapo bendru žmonijos progresu.

Industrinis dizainas - tai daiktų kūrimo praktika, taikoma masinei gamybai, iš anksto numatant norimas daikto savybes ir pritaikant gamybą automatizuotam procesui, kuriame daikto galutinę išraišką veikia ne tik jo pradinė idejja, bet ir specifiniai gamybiniai procesai. Automatizuota masinė gamyba sumažina gamybos kaštus, bet ịpareigoja gaminti didelius kiekius. Dažnai toks procesas išlieka ir gana limituojantis, kokią fizinę išraišką igyja daiktai. Pavyzdžiui - metalo plokštelès lenkimas dviem kryptimis, tiek per ilgị, tiek per plotị, yra sudètingas ir brangus procesas. Todèl masinès gamybos kontekste būtų pasirinktas vienos krypties lenkimas. Taip galiausiai liekant prie lakoniškos daikto formos. 
Industrinis dizainas - vis dar dominuojanti daiktų kūrimo ir gamybos praktika. Peršasi išvada, kad tai taip pat praktika, kuri labiausiai prisideda prie to, kaip mes daiktus suvokiame ir vartojame. Tikiu, visi esame girdèję posakius apie industrinio dizaino praktiką, tokius kaip „mažiau yra daugiau“, „forma seka funkcija“ arba „geras dizainas yra nematomas dizainas“. Tai posakiai, apibūdinantys, ịprasminantys ir paaiškinantys masinès gamybos daiktus ir jų išraišką. Visada šiek tiek stebẻjausi, kaip taikliai vos keliais žodžiais galima nusakyti dizaino praktiką. Šiandien šie posakiai yra tapę daiktų dizaino folkloru. O dizaino problematikos kontekste netgi yra ydingi. Pradėdamas atskirai nagrinèti kiekvieną frazę, supranti, kad šiandienos kontekste jos veikiau bando pateisinti, nei paaiškinti praktikos savybes. Pabrěžiamas paprastumas dažnu atveju yra ne pasirinkimas, bet gamybos galimybė. Tai paaiškina ir vyraujančią modernistinę estetikos manierą. Lakoniška daikto išraiška reflektuoja tai, kad daikto funkcija buvo pasiekta atlikus kuo mažiau gamybinių žingsnių. Tačiau galima įžvelgti ir procesą, vykstantị atvirkščiai - limituota gamybinė bazè, formuodama galutinę daikto fizinę išraišką, keičia daikto funkciją. Taigi vardan plataus daiktų pasiekiamumo industrinis dizainas gali aukoti visavertį daikto potencialą.

Industrinio dizaino procesas glaudžiai siejamas su masine gamyba ir komercine rinka, pateikdamas galutini dizainą, neatskleidžia ir viso savo kūrybinio proceso. Dalis procesų, tokie kaip gamybos derinimas, kaštu taupymas, gamybos logistika, sandèliavimo efektyvumas, technologiju pritaikomumas ir t. t., yra nematomi galutiniam vartotojui. Taigi likę neįvardyti masinio daiktų kūrimo procesai, pristatant dizainą visuomenei, tampa antraeilèmis savybèmis, o pats daiktas lieka ne visai ịvertintas.

Vienas pagrindinių gero dizaino vertinimo kriterijų industrinio dizaino kontekste yra kiekis. Kuo daugiau parduodama, tuo produktas yra sèkmingesnis. Tačiau to pačio dizaino probleminiame, arba tvarumo, kontekste kiekis tampa kvestionuojama dizaino proceso savybe, kaip pasekme, tiesiogiai prisidedančia prie perteklinės gamybos ir vartojimo ịpročių skatinimo.

Suprasti industrinio dizaino paradoksalumą gali mano viena mėgstamiausių kẻdžių - monobloc. Nors kai kam gali būti negirdètas šis vardas, kèdę visi puikiai pažista. Tai balta plastikinè kẻdè su porankiais. Neturinti 
papildomu detaliu, pagaminta kaip vienas monolitas. Sutinkama lauko kavinèse ar prie baseino. Puikiai sandèliuojama - paprastai sudedama viena i kitą. Lengvai ir pigiai gaminama, taip išlaikoma neaukšta jos kaina. Patogi. Sutinkama bet kuriame pasaulio krašte. Pritaikoma prie bet kokio kultūrinio, geografinio, socialinio ar ekonominio konteksto. Sèkmingiausiai parduodama kėdė kėdžių dizaino istorijoje, kurios kiekybės, matyt, niekas nebepralenks. Atrodytų, pagal bendrinị industrinio dizaino suvokimą - sėkmingiausia kada nors padaryta kèdè. Puikus dizainas. Geras pavyzdys. Ir tuo pačiu tai yra kėdè, kurios mes visi, lyg susitarę, nemėgstame. Praradusi bet kokị identitetą ir vertę. Iliustruojanti globalizmą ir ekologinę problematiką. Antitezè sau pačiai - pati sėkmingiausia kẻdè dizaino istorijoje yra ir pati nemėgstamiausia.

Masinė gamyba ir industrinis dizainas išliks esmine praktika, formuojančia, kaip ir kokie daiktai mus pasiekia, tačiau konvencinis industrinio dizaino suvokimas šiandien yra ir tai, kas paraleliai formuoja dizaino lauko problematiką. Iš esmės šiuolaikinio dizaino principai nesikeičia nuo Bauhauzo laikų. Racionalizuota fizinė daikto išraiška, atsisakant detalių, kurios nèra tiesiogiai susijusios su technine daikto funkcija, buvo principas norint daiktus adaptuoti masinei gamybai, kad kuo platesnè visuomenės dalis būtu aprūpinta daiktais. Šio principo aktualumas tęsėsi ir po Antrojo pasaulinio karo, kai atsikuriančiam pasauliui reikejjo minimaliais kaštais pasiekti maksimalų fizinị rezultatą. Tačiau koks šio principo aktualumas šiandienos kontekste, kai pasaulis yra apsirūpinęs daiktais? Nemanau, kad masinės gamybos neliks. Neįsivaizduoju pasaulio neglobalaus. Bet šiandien tampa svarbu pergalvoti taikomus principus ir kuriamą ryšį tarp žmogaus ir daikto.

Tiek daiktų turẻjimas, tiek jų įsigijimas šiandien tapo lengvai igyvendinama norma. Tik pati jų gamyba išliko vis dar nelengvu procesu, suprantamu siauram visuomenès ratui. Kalbėdamas apie gamybą, turiu omenyje tiek idejini, tiek ir fizini igyvendinimą. Gal nuo to ir verta pradèti galvoti, kodèl ir kaip mes suvokiame daiktus? Mano, kaip praktiko, suvokimo dalị apima ịvairūs daiktu gamybos procesai, kurie dažnai tampa priežastimi pergalvoti daiktus ir ieškoti alternatyvių daikto išraiškos būdų (dar dirbdamas industrinio dizaino studijoje March Design Studio, pasiūliau

$103-2021$

Acta Academiae Artium Vilnensis 
vietoj tradicinio projektavimo būdo sugalvotas idejjas adaptuoti vienokiai ar kitokiai konkrečiai gamybai, apvažiuoti ir susipažinti su aplink esančia pramone ir jų praktiką adaptuoti dizaino idėjoms). Sugalvotas sudètingas arba dar neišbandytas medžiaginis ar konstrukcinis sprendimas dažnai tampa iššūkiu, vedančiu kūrybinị procesą i priekį. Skirtingos formos, medžiagos, jų reikšmès, sudètingi ar standartizuoti ir plačiai naudojami gamybos būdai atspindi dizaino profesijos ir daikto santykių kompleksiškumą, skirtingą vertę ir prasmę. Minètų atspirčių užtenka, kad apsispręstum kurti daiktus, kas, manau, dažnu atveju ir nutinka, pasirinkus dizainerio profesiją. Tai yra momentas, kai tampama tikruoju materialistu ${ }^{4}$ ir pradedama nuoširdžiai žavètis visu supančiu materialiu pasauliu. Pasirinkus gilintis ị teorinį profesijos diskursą, igytą gamybinę ir medžiaginę patirtị papildo tarpdisciplininė žiūra ir performatyvioji teorijos ir praktikos santykio perspektyva ${ }^{5}$.

Bet kiek šių žinių reikia vartotojui, naudojančiam daiktą, arba gamintojui, siekiančiam ji igyvendinti? Ar jų apskritai reikia, norint naudotis daiktu pagal jo funkciją, nes tai lyg ir pirminis daikto tikslas, o gamintojui sugalvojant optimaliausią medžiagų apdirbimo ir gaminio surinkimo metodą. Ieškant atsakymų $i$ šiuos klausimus, ne tik kritinis, bet ir ịprastas industrinio dizaino diskursai skatina permąstyti dizaino praktikos metodus ir tradicijas, nes akivaizdu, kad fizinė objektų gamyba yra vartotojiškumo, perteklinės produkcijos, galiausiai ir klimato kaitos problemų dalis. Industrinis dizainas funkcionuoja globalios masinės gamybos kontekste. Tai suvokdami, apibrèžiame daiktų kūrimo pasekmių ir atsakomybių lauką. Daiktų dizaino materialūs rezultatai virsta supančio pasaulio istorija ir problematika. Dizaino istorija liudija, kad tai jau ne kartą buvo kvestionuota, permąstant gamybos procesus, naudojamas medžiagas, vartotojo ir dizainerio santyki su objektu ${ }^{6}$. Tvarumo klausimas taip pat keltas ne kartą ir jau yra tapęs bendru profesiniu leitmotyvu praktikoje ir akademiniame kontekste.

4 „Mes esam per dideli materialistai plačiaja žodžio prasme ir per maži materialistai tikraja žodžio prasme. Mes turime tapti tikraisiais materialistais todèl, kad mums turi pradèti rūpèti visa mus supanti materiali aplinka." Juliet Schor, Minimalism: A Documentary About the Important Things (2015).

5 Michelkevičius, Meninio tyrimo suvesti. Žinojimo kontūras, 18.

6 Italų radikalusis dizainas (Italian radical design), XX a. 6 deš. antra pusė, Italija; The Construction School, ịkurta 1964 m., Jungtinė Karalystė; Dalyvaujamasis dizainas (Participatory design), XX a. 7 deš. antra pusè, Skandinavijos šalys; Naujasis vokiškas dizainas (Neues Deutsches design), 1980, Vokietija; Memfio judejjimas (Memphis movement), 1980, Italija; Droog dizainas (Droog design), 1990, Nyderlandai; Karališkasis menų koledžas (Royal College of Arts), 1997, Jungtinė Karalystè. 
Niekas dizainerių nemoko kurti prastų daiktų. Niekas nemoko jų kurti tokių daiktų, kurie po vieno sezono jau būtų moraliai ar fiziškai pasenę. Atvirkščiai - yra ugdoma atsakomybè, pagarba ir atidumas, puoselëjant daiktą, nes gamybos procesas yra per daug brangus ir sudètingas, kad šiu nuostatų būtų galima nesilaikyti. Tačiau kiekvienas dizaineris ir kiekvienas naujas daiktas, ateinantis ị ši pasauli, atsineša savotišką ,pirmają nuodèmę" - jis buvo padarytas - ir išsyk tampa bendrų problemų dalimi. Faktiškai nesvarbu, kokį daiktą sukursi - turėdamas fizinị pavidalą, jam gimstant vienaip ar kitaip naudojami resursai ir finansai. Imant spręsti, ar daiktas vertas egzistuoti, formuojasi nauji vertinimo kriterijai, besiremiantys daikto fiziškumu?: medžiagų ekologiškumas, sandèliavimo (logistikos) racionalumas, gamybinio proceso efektyvumas ir, žinoma, refleksija - kaip daikto funkcija galimai sprendžia pasirinktą problemą. Vertinama, kuris daiktas mažesniais kaštais atliks tą pačią funkciją arba kuris gamybos principas bus universalesnis ir galès būti pritaikomas skirtingose situacijose. Man visada kyla klausimas - ar daiktas, atitinkantis išvardytus kriterijus, padidina ar sumažina bendruosius daiktų gamybos kiekius? Juk iš esmès bet kuris sukurtas daiktas skatina vartojimą ${ }^{8}$. Dažnai industrinio dizaino profesija yra ivvardijama kaip tiesiog gamybos poreikius puoselejjanti veikla, o ne daikto kūrimo praktika, „daikto“ sampratą pakeičianti ị „prekès“9. Tai redukuoja daiktą tik iki jo kuriamos fiskalinès naudos rinkai. Ir iš asmeninès patirties komercinio dizaino kontekste galiu pasakyti, kad dažnai „geros idejjos“ nugula stalčiaus dugne, nes yra per brangios igyvendinti.

Štai pavyzdys: buvau nuoširdžiai nustebęs, kiek turiu pieštukų, tušinukų ir kitų rašymo priemonių [1 il.]. Teko visus organizuotai surinkti ì vieną vietą, kraustantis ị naują studiją. Supratau, kad turbūt galiu nebepirkti rašymo priemonių iki gyvenimo galo. Tai privertė pagalvoti, kokia

7 „Nors tyrimas, kaip priemonė, yra vis dažniau taikomas nagrinėjant dizaino istoriją ir šiuolaikinę praktiką, dizaino kritika lieka nuošalyje. Dažniausiai dizaino kritika yra suvokiama kaip supaprastinta daikto funkcija, redukuota iki pragmatinio daikto suvokimo." Matt Malpass, Critical Design in Context: History, Theory, and Practices (New York: Bloomsbury Publishing, 2017), 78.

8 „Dizaino profesija turi subręsti ir atrasti būdus, kaip veikti už griežtų paslaugų pramonès apribojimų ribų. Blogiausiu atveju produkto dizainas tiesiog sustiprina globalias kapitalistines vertybes. Dizainas turi suvokti situaciją ir sukurti sau alternatyvius vaidmenis. Dizainas turi nusistatyti savo intelektualinę poziciją arba dizainerio profesija praras bet kokị intelektinị poveikị ir liks tiesiog komercinės rinkos ịrankiu (Dunne ir Raby 2001, 59).“ Ibid., 8.

9 „Iš esmès italų kritinis dizainas sukuria judejjimą, kuris produkto ir industrinio dizaino kontekste susiformavusi dizainerio vaidmeni - tenkinti vartotojo ir rinkos poreikius - keičia ị labiau prasmingą praktiką, kuri remiasi diskursyviu poreikių formavimu.“ Ibid., 18. 


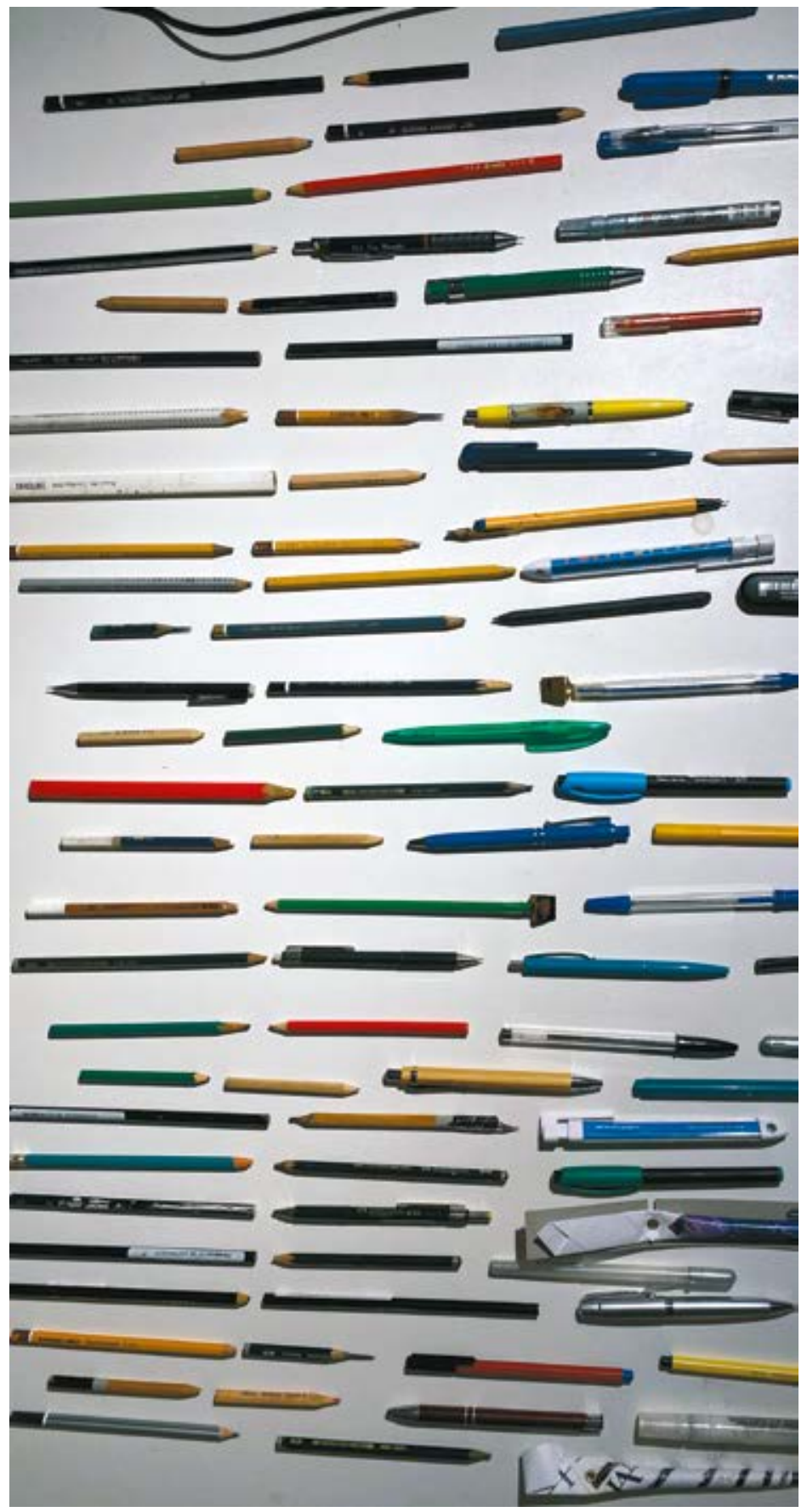

Vytautas Gečas, 100 tušinuku, 2020, nuotrauka, $35 \times 18$, asmeninis archyvas
Vytautas Gečas, 100 ballpoint pens, 2020, photo, $35 \times 18$, courtesy of the artist 
yra tušinuko, kaip daikto, vertè, jei jo fizinè vertė man nebeegzistuoja. Ne tik dèl to, kad turiu jų labai daug, bet labiau todèl, kad tiek daug jų prisirinkau, faktiškai neskyręs tam laiko. Didžiosios daugumos tų rašymo priemonių aš nepirkau, bet „gavau“. Spalvų, formų ir logotipų ìvairovè taip pat byloja, kad „kolekcija“ buvo renkama ne iš vieno šaltinio. Tušinukas tapo objektu, turinčiu aiškią fizinę formą ir funkciją, bet praradęs ekonominę vertę, man taip pat prarado ir daiktinę. Kiek tušinukas, kaip daiktas, yra nuvertinamas, tapdamas taip dažnai nemokamai dalijamu daiktu? Nors viešose vietose atvirkščiai - jis būna prirakintas grandinèle, kas liudija, jog žmonės juos savinasi, nes tai yra daiktas, virtęs beverčiu. Taigi daiktas, puikiai atlikdamas savo funkciją, praranda savo vertę. Ar funkcija praranda savo vertę daikte? Ar funkcijos vertės daikte mums nebeužtenka? Ar tai pavyzdys, kaip industrinio dizaino praktika mus apgauna, pakeitusi daikto suvokimą ir jo vertę?

\section{Dizainas kaip apgaulè}

Iš daugelio įvairių semantinių žodžio „dizainas“ (design) reikšmių labiausiai atkreipia dėmeș šios: klastingas (cunning) ir apgaulè (deceit) ${ }^{10}$. Šiuo atveju klasta ar apgaulè gali būti suvokiamos tarsi veikimas prieš fizikos ar gamtos dèsnius, kai daiktas ir jo dizainas virsta įrankiu, praplečiančiu mūsu fizines galimybes ${ }^{11}$. Tačiau perteklinès ir vartotojiškos kultūros kontekste prasmė gali būti visai kita. Platonas apgaulę aptaria meno ir technologijos kontekste $^{12}$, teigdamas, kad, bandant materializuoti idèją, ji neišvengiamai yra iškreipiama ir keičiama. Abstrakčiam, nevizualiam mąstymo procesui suteikiant fizinę išraišką, kad ir piešiant eskizą, ankstesnei beformei būklei yra duodamas kūnas, kurị suformuoja mūsų mąstymas arba net fiziniai sugebėjimai (pvz., piešti). Jei kokiu nors būdu galètume perkelti tą pačią idèją i atskirų žmonių sąmones, jų nupiešti eskizai šiek tiek (o gal ir labai) skirtųsi. Taigi materializuojant idejja yra keičiama ir taip „,išduodama“ pradinė jos forma.

„Being a human being is a design against nature," ${ }^{13}$ - iddomu, kaip keistųsi dizaino profesija, jei dizaino kursas būtų pradedamas dèstyti šiais 1999), 32.

10 Vilem Flusser, The Shape of Things, A Philosophy of Design (London: Reaktion books,

11 Ibid., 33.

12 Ibid., 34 .

13 „Ką mes apgaudinėjame kurdami kultūrą (kurdami meną, technologijas - kitaip sakant, dizainą)? Pavyzdžiui: svertas yra paprastas daiktas. Jo konstrukcija atkartoja žmogaus rankos struktūrą; svertas yra dirbtinè ranka. Sverto konstrukcijos technologija yra sena kaip pati žmonija, gal net dar senesnè. Ir šis daiktas, šis dizainas, šis meno kūrinys, ši technologija yra skirta pergudrauti 
žodžiais. Apima neviltis, nes atrodo, kad dizaino lauko problemos (ypač masinès gamybos ir klimato kaitos kontekste) buvo nuspėjamos arba užprogramuotos nuo pat dizaino pradžios. Lyg jis būtų „grynas blogis“, sukurtas tik kenkti. Tačiau nepasidavus pirmam ịspūdžiui ir pabandžius įvardyti situaciją, požiūris keičiasi. Juk visa ịvairialypè, daugiasluoksnè, kompleksinè dizaino praktika ir procesas įvardijami vienu žodžiu ir atliekamu vaidmeniu - apgaulè. Leidžiu sau laisviau interpretuoti šio žodžio reikšmę. Kaip mus apgauna kėdè? Kad galime sėdèti tam tikrame aukštyje, o ne ant žemės? Tokiu būdu mes patys apgauname, o gal tikriau įveikiame gravitaciją. Tai tampa fizine daikto - kèdès - savybe, taigi dizaino praktikos materialius rezultatus galime pavadinti nuolatine kova su gravitacija. Apgaulès būdu mes vieną situaciją pakeičiame kita. Neigiama žodžio design reikšmė (apgauti ir klastoti) atspindi dizaino mąstymo gebėjimą projektuoti kaitos procesa per daiktą.

Dizaino sampratoje užkoduota tai, kad jo procesas keičia vieną situaciją kita. Kaip apgaulès samprata aprèpia dvi situacijas: tai, kas buvo žadèta, ir tai, kas buvo pateikta, taigi ir dizaino procesas turi pradinę situacija ir galutinę, paveiktą dizaino intervencijos. Apgaulès galutinė situacija yra blogesnè nei žadèta pradinè, todèl šis žodis turi neigiamą konotaciją. Bet jei atsisakytume vertinti emociškai, matytume, kad viena situacija po apgaulès tiesiog tampa kita. Šis principas būdingas ir dizaino procesui. Tai yra apgaulè be savanaudiško tikslo ir potencialiai neigiamų pasekmių. Netgi priešingai - dizaino procesas siūlo esamą situaciją pakeisti geresne. Kaitos rodiklis tampa esminiu leitmotyvu dizaino praktikoje ir jos tikslu. Tačiau kokia yra kaitos kuriama vertė? Kaip ji kinta, kai yra keičiama spalva ar forma arba kai iš principo yra permąstoma visuma, pateikiant ją nauju, dar nematytu pavidalu? Ar gali būti ịvestas kaitos indeksas? Ir ar mūsų vartojimo ịpročiai nèra susiformavę taip, kad vartojame nebenutuokdami apie tą pradinę, pirminę, situaciją? Kiek tai galètų būti svarbu, vertinant ir naudojant daiktą?

gravitaciją, apgauti mūsų aplinkos dèsnius, gudrybės būdu juos apeiti strategiškai išnaudojant gamtos dèsnius. Naudodamiesi svirtimi - nepaisant mūsų kūno svorio - galètume iškelti save iki pat dangaus, ir - su svertu - su keliamaja konstrukcijos galia galètume iškelti žemès planetą iš jos orbitos. Sverto veikimo pavyzdys yra visos kultūros pagrindas: apgauti gamtos dèsnius pasitelkiant technologijas, pakeisti natūralias sąlygas ir sukurti tam skirtą daiktą, kuris manipuliuoja gamta už žmogaus fizinių gebėjimų ribų." Ibid., 38. 


\section{Industrinio ir kritinio dizaino strategijos}

Svarbus klausimas yra ir kaitos mastelis - ar turime omenyje vieno individo kaitą, pavyzdžiui, perkančio naujus „IKEA“ baldus savo namams, ar gamintojo, taikančio naujus principus gamyboje, projektavime, medžiagose, produkto pateikime, idėjose, ar visos visuomenès kaitą, kvestionuodami esminius leitmotyvus daiktų gamyboje ir jų suvokime? Daikto mastelyje svarbūs klausimai yra, ar norėdami atnaujinti daiktą ir jo dizainą, keičiame, pavyzdžiui, jo spalvą arba konstrukciją, arba funkciją? Kuris iš šių trijų „mastelių“ yra dažniausiai puoselèjamas industrinio dizaino kontekste, o kuris kritinio? Lyg ir aišku. Industrinis dizainas, matyt, dažniau keis tik vizualias daikto charakteristikas, o kritinis principingai pasirinks interpretuoti savybes, kurios iš esmès kvestionuos daikto identitetą ${ }^{14}$. Bet ar iš principo, siekdami didesnio kaitos potencialo ir keisdami daikto funkciją, neprarandame ryšio su pradiniu tašku, pačiu pradiniu daiktu? O tokia taikoma metodologija tampa sunkiai suprantama konvencinio daiktų kūrimo procese bei industrinio dizaino kontekste.

Kritinis dizainas, gilindamas santykio tarp objekto ir žmogaus supratimą, tampa platesnès kritinès socialinès teorijos dalimi ${ }^{15}$ ir atskleidžia dizaino profesijos vaidmeni sociotechnologiniame, ekonominiame, politiniame, kultūriniame ir psichologiniame kontekste. Kritinis dizainas per objektą siekia įtraukti vartotoją ar žiūrovą ị situaciją, kurioje jis labiau susimąstytų apie daiktą, kartu atskleisdamas, kaip daiktų pasauli mato ir suvokia dizaineris. Kontroversiškoje kritinio dizaino praktikoje glūdi sukoncentruota dizainerio patirtis. Tarp realybės ir fikcijos varijuojantis kritinis dizainas reflektuoja žmogaus vartojimo ịpročius. Jo tikslas yra išlaikyti dizaino profesijos budrumą.

Vartotojo noras turèti naują daiktą pasąmoningai siejasi su naujos realybės arba kaitos siekimu. Dizainas patenkina ši žmogaus poreikį, tačiau viena sritis to siekia tiesiogiai, o kita pasitelkia dar ir kritinị žmogaus bei jo aplinkos vertinimą.

14 „Kritinis dizainas meta iššūkị hegemonijai ir dominuojančiai ideologijai mokslo, technologijų, socialinès lygybès ir neginčijamų disciplininių normų kontekstuose. "Malpass, Critical Design in Context: History, Theory, and Practices, 6.

15 „kritinio dizaino praktika siūlo dizaino procesus kaip metodus, plètojančius kultūrinę kritiką, tokiais klausimais kaip biomokslai, bioinžinerija, medicina, aplinkosauga ir t. t., taip formuodama socialinị, institucinị ir intelektinị diskursą viešajame kontekste." Ibid., 69. 
Kritinis dizainas formuojasi už komercinès rinkos ir masinės gamybos ribų, taip kvestionuodamas praktiškumo, technologijų ir fiskalinės naudos konvencinę sampratą. Dažnai kuriami eksponuoti, bet ne parduoti, kritinio dizaino kūriniai neatsako ị išsikeltą problematiką, bet ją nagrinejja teoriniame ir socialiniame diskurse. ${ }^{16}$

Keliu hipotetinị klausimą: gal reikia pradėti gaminti daiktus, kurie būtų sunkiai pagaminami arba sunkiai naudojami, t. y. iš principo elgtis priešingai, nei yra ịprasta? Taip atsisakytume žalingos masinès gamybos, o įdètas darbas taptų papildoma pridètine verte. Pergalvokime daikto vertę, atimdami iš jo tai, kas dabar daiktą padaro daiktu - funkciją, taip keisdami suvokimą apie tai, kas tapo kasdieniška, todèl nebepastebima ir nebevertinama. Tokius daiktus - neigiančius funkciją - galima sieti su nauju kūrybos metodu, padedančiu sukurti naują fizini daikto pavidalą arba suvokti kaip dizaino ịranki projektavimo proceso ir daiktų savybių tyrimui. Pradedi vertinti, ką turejjai, tik tada, kai tai prarandi. Tokia kvestionuojanti praktika ịsitvirtinusios industrinio dizaino praktikos kontekste siekia persvarstyti daikto potencialą, jo reikšmę ir suvokimą - aspektus, apie kuriuos jau lyg ir nebereikia mąstyti pirmiausia dèl plataus daiktų pasiekiamumo. Kvestionuoti yra ịprasta šiuolaikinio meno lauke - tai būdas atkreipti dèmesị i tam tikrą problematiką ir kvietimas diskusijai. Kritinis dizainas iš esmės naudoja tas pačias priemones, formuluodamas savo diskursą $a^{17}$. Galbūt dèl to kritinio dizaino diskursas yra dažnai pavadinamas meno praktika - ,jeigu jau ant kèdès negalima atsisèsti $^{* 18}$. Prie to prisideda ir kritinio dizaino konceptualumas ir platus teorinis kontekstas, pristatomas paraleliai su objektu (jei jis apskritai yra) ${ }^{19}$.

16 Ibid., 4.

17 „Kritinio dizaino praktika pasirenka meninị tyrimą kaip būdą kvestionuoti dizainą, mokslą ir visuomeninius interesus. Dažnai perimdamas erdves, tradiciškai skirtas meno laukui, kritinis dizainas pasitelkia galerijos kontekstą kaip būdą atkreipti dėmesị ị rūpimus klausimus. Pasitelkdamas meninị tyrimą ir meno galerijos erdves kaip veikimo kontekstą, kritinis dizainas iš esmès pasirenka taikyti konceptualaus meno metodus savo praktikoje. Tačiau praktikos pagrindu išlieka kasdienių daiktų vartojimo įpročiai.“ Malpass, Critical Design in Context: History, Theory, and Practices, 11.

18 ,Vystantis kritinio dizaino praktikai, buvo prasminga ieškoti teorinio pagrindo disciplinose, nesusijusiose su pramoniniu dizainu. Nors tokia praktika ir buvo taikoma anksčiau, ji dažniausiai analizuodavo estetiką ir vizualiają kultūrą. Kritinio dizaino artimas santykis su konceptualiu menu formuoja meno kritikos tradicijas dizaino kontekste. Tai galima identifikuoti ir dažnai girdint kritinio dizaino praktiką ịvardijant kaip „meno dizainą“ (design art), kas pagal Joe Scanlaną yra tik abstrakti frazè, iš esmès taikytina bet kuriam meno kūriniui, kalbančiam apie erdvę, funkciją ir stilių taikomuju menų kontekste (Coles 2002).“ Ibid., 72.

19 „Jie apibrèžia pasakojimo ir naratyvo svarbą kritinio dizaino praktikoje. Tačiau šios priemonės nèra pasiekiamos per tiesioginị daikto vartojimą, bet per retorines naudojimo strategijas." Ibid., 47. 
Logiška - siekiant revizuoti ịprastą industrinio dizaino praktiką, ieškoma naujų praktinių ar teorinių aspektų, leidžiančių sukurti naujas daikto savybes arba pakeisti senąsias. Juk naudojant tuos pačius įrankius, gautussi labai panašus rezultatas. Ir dizaino istorija rodo, kad, taikant tik fizinius pakeitimus arba išliekant masinės gamybos kontekste, kritinė praktika greitai būna adaptuojama komerciniame kontekste, taip iš esmès nieko nepakeisdama ir net prisidėdama prie problemos gilinimo (pvz., Enzo Mario autoprogettazione? projektas ir „IKEA“(20).

Yra ir kita medalio pusè. Kritinio dizaino praktika neretai nebekoreliuoja su kontekstu, ị kurị pasirenka žvelgti kritiškai. Nefunkcionalių daiktų kūrimas jau tapo išnaudota, iliustratyvia idejja su dažnai nuspejjamu arba nuasmenintu rezultatu, kuris nebėra susijęs nei su pačiu daiktu, nei su eskaluojama problematika. Todèl kritinio dizaino diskursas gali pasirodyti uždaras ir klaustrofobiškas ${ }^{21}$. Radikalumas išlieka tik būdu atkreipti dèmesį i problemą, bet nebūtinai ją spręsti. Pasirinktos kontroversiškos ir konceptualios strategijos, nors ir logiškai konstruojamos, atsiduria priešingoje pusėje nei konvencinio dizaino veikimo būdai. Susidaręs atstumas apsunkina išsikeltus kritinio dizaino tikslus - per kritinę praktiką papildyti, keisti industrinio dizaino praktiką. Kritinio dizaino metodų taikymas masinėje gamyboje neabejotinai nelengva užduotis, kyla abejonių, ar šios dvi sritys gali sietis.

Dèl to kritinio dizaino praktika tarsi tampa intravertiška, skirta tik siaurai dizaino bendruomenei ${ }^{22}$, o praktiniai jos rezultatai, susiję su vartotoju, išlieka tik numanomi. Tokią atskirtį būtų galima mėginti aiškinti siekiu pakeisti situaciją kaip galima greičiau. Kas iš pradžių atrodo nebrandu, gali būti prasminga, pavyzdžiui, turint omenyje ekologinį dizaino kontekstą. Kritinė praktika dizaino lauke, nors istoriškai formavosi paraleliai

20 Enzo Mario projekte autoprogettazione? pateikiama tik baldo instrukcija, taip kvestionuojamas žmogaus ir daikto santykis. „IKEA“ panašiu metu tokią praktiką adaptuoja masinei baldų gamybai, sandèliavimui ir pateikimui. Komercinio dizaino kontekste kritinè praktika paverčiama ekonomine mažumos nauda.

21 „teigia, kad kritinio dizaino praktika dažnai atrodo radikali, bet paprasčiausiai gali būti užmaskuota kaip radikali, nes pateikto kūrinio eskaluojamas šokas ir kontroversiškumas prasilenkia su žiūrovo vartojimo lūkesčiais. Diskusija reflektuoja į dizaino mokslininkų nuomonę, kad kritinis dizainas nesugeba veikti už meno ir dizaino praktikų ribų. $\mathrm{O}$ praktikuojantys dizaineriai iš esmès diskutuoja tarpusavyje, taip ne spręsdami išsikeltos problematikos, bet veikiau analizuodami fikcinius scenarijus.“ Malpass, Critical Design in Context: History, Theory, and Practices, 3.

22 ,Vis didesnị pavojų kelia tai, kad kritinio dizaino praktika tampa pernelyg savirefleksyvi ir uždara, palaikoma ir praktikuojama uždaroje bendruomenėje.“ Ibid., 8. 
industrinio dizaino raidai, ilgą laiką buvo ir tebėra puoselëjama tik akademiniame diskurse ${ }^{23}$. Taigi industrinis dizainas vis dar dominuoja kuriant daiktus, gaminant ir vartojant. O jeigu abi praktikos būtų lygiavertès? Dabar daiktų suvokimą daugiausia formuoja industrinio dizaino diskursas, $i$ daiktus skatinantis žvelgti per vartotojo prizmę, daiktui tampant pirmiausia preke, o dizainui - globalios ekonomikos dalimi. Tuo tarpu kritinio ir konceptualaus dizaino praktika, dažnai neribojama rinkos veiksnių ir daikto komercinės sèkmės (pardavimų kiekybės) siekio, gali atrodyti tarsi nenaudingų daiktų kūrimo scenarijus ${ }^{24}$. Kvestionuodamas platesnę, ne tik fizinę, daikto vertę arba ittaką žmogui, kritinis dizainas dažnai remiasi kūrybiniu tyrimu, kuriam gali trūkti aiškaus materialaus pagrindimo. Ši praktika skatina subjektyvų požiūrị, nevienareikšmius sprendimus, formuojant galimus alternatyvius scenarijus ar objektus, leidžiančius atrasti kitą, ne tik fizinę, daiktų vertę. Kitaip tariant, kritinio dizaino praktika skatina užduoti daugiau klausimų, negu bandyti ị juos atsakyti25.

Kritinis dizainas, kuriamos dizaino fikcijos parodo, koks pasaulis galètų būti. $\mathrm{O}$ industrinis pasaulis, remdamasis vyraujančiais dizaino metodais, rodo, koks pasaulis yra ${ }^{26}$. Vieni galvoja apie šiandieną, kiti - apie rytojaus scenarijus. Ir vieni, ir kiti yra svarbūs.

\section{Problemos sprendimas ar jos kūrimas?}

Dizainas sprendžia problemas, todèl „gero“ dizaino procesas visuomet turi prasidèti nuo to, kad pasirenkama tam tikra problema. Taip apibūdinamas dizaino procesas, stengiantis išvengti daiktų, kurie būtų kuriami tik dèl estetinio pasitenkinimo, nes to tarsi nepakanka. Bet man atrodo, kad

23 ,didžioji kritinio dizaino praktikos dalis, vykdomos šiandien, yra susijusi su akademinèmis institucijomis ir dažnai yra apibūdinamos tik kaip šiame kontekste atliekamas tyrimas." Ibid., 38.

24 „Moline'as (2008) ir Maze (2007) teigia, kad be formalios analizès ir rimto dizaino tyrèju bendruomenès įsikišimo kritinè dizaino praktika iš šalies gali būti suvokiama tik kaip paviršutiniška produkto dizaino forma. Jie pripažista, kad dizainui svarbu reflektuoti kuriamų produktų ir praktikos ittaką ir išnaudoti dizaino praktiką, kaip sprendžiančią pasirinktą problematiką ir ją nagrinėjančią." Ibid., 10.

25 ,tai parodo, kad kritinis dizainas, kaip tyrimo metodas, nėra objektyvus ar paaiškinantis. Kritinis dizainas kritikuojamas ir dèl to, kad kūrybinis procesas ir jo rezultatas išlieka moksliškai neapibrèžiami. Kritinis dizainas, priešingai nei industrinis, puoselèja subjektyvumą, dviprasmybę ir objektą, kaip ịrankị provokuoti. Trumpai tariant, kritinis dizainas, kaip tyrimo metodas, siekia užduoti daugiau klausimų, nei atsakyti.“ Ibid., 14.

26 „Dizaino fikcija yra svarbi, nes ji suteikia mums galimybę pamatyti pasaulį ne tik tokị, koks jis yra, bet ir koks jis galètų būti. Tai būdas realizuoti idèjas ir scenarijus be pragmatišku konvencinio dizaino suvaržymų." Ibid., 54. 
dizainas faktiškai kuria tas problemas ${ }^{27}$. Žodis „sprendžia“ yra skirtas vartotojui, kad šis teisingai suprastų daikto vertę. Minètą problemų kūrimą reikètų perfrazuoti i jų identifikavimą. Daiktai tampa mūsų ịpročių liudininkais, o dizaineriai - objektyviais kasdienybės stebètojais. Analizuojama situacija ir atliktas tyrimas formuluoja naujus poreikius, kurie tampa dalimi kūrybinio dizaino proceso, keliant profesines užduotis.

Taigi dizainas kuria problemas, nes žmogus kartais net nesusimąsto, kad jų yra. Būtent dizaineris, stebėdamas aplinką, žmogaus elgesi ir ịpročius, gali identifikuoti problemą (taip ją sukurdamas) ir îvertinti, kaip situaciją galima pakeisti geresne naudojantis dizainu kaip ịrankiu. Aiškus dizainerio vaidmens ịvardijimas - aš kuriu problemas, o ne jas sprendžiu visai kitaip veikia atsakomybės suvokimą praktikoje. Atrastas fizinis sprendimas nebūtinai tampa galutiniu rezultatu. Daikto projektavimo procesas ir daikto įtaka prasiplečia už paties daikto ir jo funkcijos ribų. Dažnai galvoju - juk šumerų niekas neprašè sukurti rato, ar ne? O sukurtas ratas, besisukdamas palengvina buitị arba ją pagreitina? Manau, kad situacijos jis nepalengvina, bet ją keičia mažindamas žmogui fizinị krūvị. Panašiai išmanusis telefonas turèjo palengvinti darbą, kad i svarbų elektroninị laišką būtų galima atsakyti iš bet kur. Tačiau buvo pradèta tai daryti ne tik iš bet kur, bet ir bet kada, ir be galo. Taigi dizainas ne panaikina probleminès situacijos, ją galimai išspręsdamas, bet keičia vieną situaciją kita. Daiktas tampa tarpininku tarp dviejų situaciju - pradinès probleminès ir galutinès, kurioje nebelieka prieš tai buvusių nepageidaujamų trikdžių. Tai nėra ta pati tiesiog kažko atsisakius situacija, veikiau - iš esmès nauja padètis. Ši nauja realybè ir tampa daikto veikimo kontekstu. O dizaineris projektuoja ne tik daiktą, bet ir pačią situaciją. Taigi galima sakyti, kad dizainas ne taiso aplink mus esantị pasaulį, bet įsivaizduoja ir projektuoja naują ${ }^{28}$.

Ar tokiame procese dizainerio mąstymas taip pat turi keistis? Ar siekdami sukurti kitoki, naują, scenarijų, turime daiktą projektuoti dabarčiai, eliminuodami esančią problemą, ar ateičiai, kurioje daiktas egzistuos

27 „Kritinè ir reflektyvi praktika keičia produkto dizaino funkciją iš problemų sprendimo i kontekstualią problemų paiešką ir jų nagrinèjimą. Šios išplèstinės praktikos įtaką galima įžvelgti, kai kritinio dizaino praktika yra vis dažniau pasitelkiama disciplinose, nesusijusiose su dizaino profesija. Išnaudojant praplèstą tyrimo potencialą, kaip formuojantị iššūkius, o kartais ir priimantį aktyvistinę poziciją.“ Ibid., 51.

28 ,tai buvo skirta atkurti alternatyvių scenarijų kūrimą produkto ir vartotojo sąsajos dizaino kontekste, pasakojant istorijas apie žmogaus vertybes ir elgesi, kas tapo pamiršta pramoninio dizaino praktikoje.“ Ibid., 13. 
jau išsprendus problemą. Gal mąstant, kaip žmogui patogiau sėdėti (dabartis), reikia galvoti, kaip tai pakeis jo realybę ir santykị su likusia aplinka (ateitis)? Tuomet atitinkamai reiktų pergalvoti ir daiktiškąsias dizaino objektų savybes, kurios būtų vertingesnès ateities scenarijui. Steve'as Jobsas, kurdamas „iphone'ą“, galvojo ne tik apie jo formą, patogų valdymą, išvaizdą, gamybos kaštus, bet ir apie informacijos pasiekiamumą bei tiesioginiu bendravimu sujungtą pasauli. Taip formuluojama problema veikiau tampa inspiracija, kuriant naują daiktą, bet ne priežastimi ar tikslu. Daikto potencialas prasiplečia už konkrečios problemos ribų.

\section{Daikto funkcija}

Funkcija yra daikto esmè. Su tuo turbūt sutiktų daugelis įvairių dizaino sričių atstovų. Daikto atliekama fizinè funkcija yra jo egzistencijos pagrindas. Funkcija egzistuoja dar iki daikto, todèl yra daug ịvairių būdų tai pačiai funkcijai atlikti, o dizaino procesas bando identifikuoti, kuris iš ju yra geriausias.

Savo praktikoje ne kartą ịsitikinau, kad išspręsčiau išsikeltą problemą, rasčiau, kaip atlikti funkciją, galima ịvairiai. Proceso metu, detaliai ivertinus ir kitas daikto veikimo aplinkybes (gamyba, estetika ir t. t. ), galiausiai yra pasirenkamas vienas variantas. Kurdamas supranti, kad funkcija yra neapibrèžtas, abstraktus dalykas ${ }^{29}$, lydimas dizainerio vaizduotės ir patirties. Igydama skirtingus pavidalus įvairiuose daiktuose, funkcija ima plèsti suvokimą apie save. Ta pati funkcija gali igyti daug skirtingų reikšmių, igaudama naują fizinị pavidalą, arba būti ịvairiai suvokiama skirtinguose kontekstuose ar situacijose ${ }^{30}$. Funkcija yra lankstus, dinamiškas, gyvas, besikeičiantis procesas, vykstantis daikte. Tai iš pradžių gali būti sunkiai suvokiama žiūrint ị daiktą, kuris dažnai be žmogaus pagalbos net negali pajudèti iš vietos. Dažnai kieta, tvirta daikto konstrukcija ir medžiaginè išraiška (rašydamas galvoju apie baldų dizainą) suponuoja monumentalumą tiek jo fizine, tiek funkcine išraiška - vienai pasirinktai funkcijai atlikti daikte yra skirta viena konstrukcija, viena išraiška. Bet man visada nuoširdžiai, o gal naiviai atrodo,

29 „funkcija yra reliatyvi ir situacinė; tai yra dinamiška savybė, besiremianti subjektyvumu, bet ne nustatyta fiksuota tvarka." Ibid., 81.

30 ,The function of an object can therefore be as a symbolic communication concept, and a matter of understanding between the design and user. Function might be understood as the perception of use, which emphasizes the appropriation of he object through the user according to their particular needs, involving what Maze describes as '...processes of interpretation, incorporation, and appropriation into the user's lifeworld (Maze 2007, 2).“ Ibid., 82. 

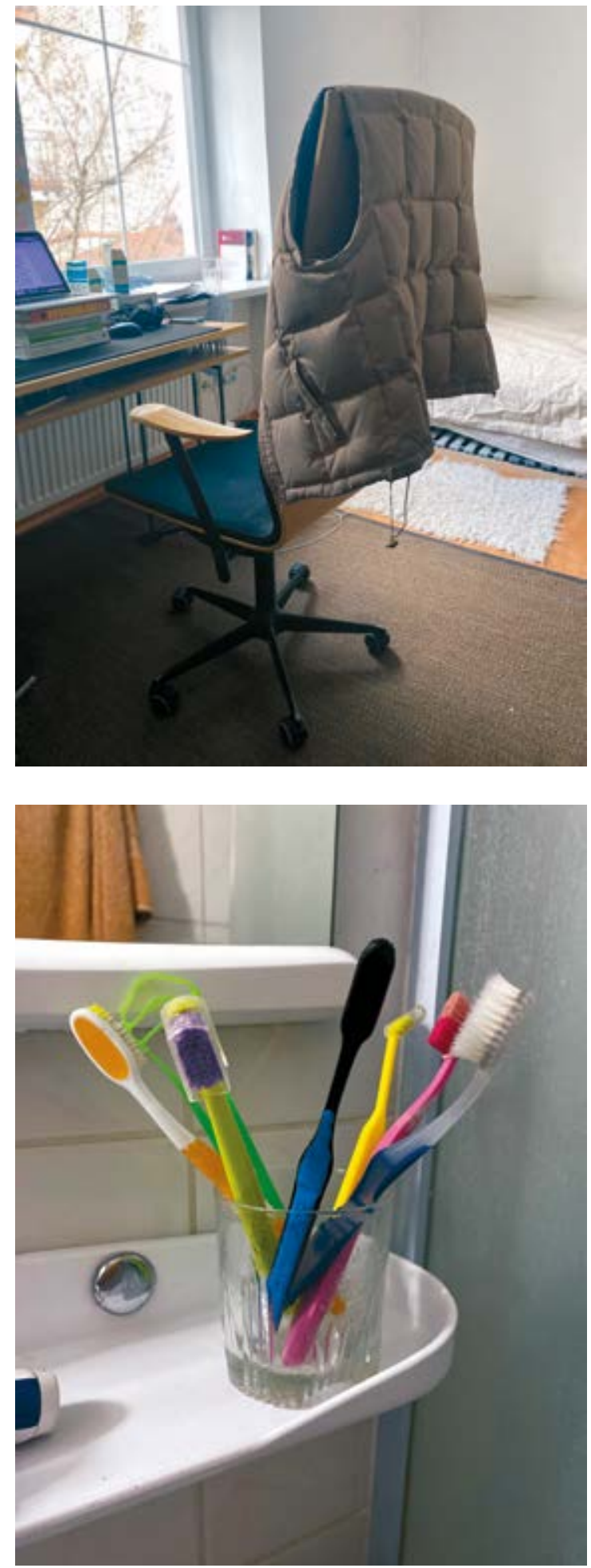

2.

Vytautas Gečas, be pavadinimo, 2021, skaitmeninè nuotrauka, $35 \times 25$, asmeninis archyvas

Vytautas Gečas, Untitled, 2021, digital photo, $35 \times 25$, courtesy of the artist.

3

Vytautas Gečas, be pavadinimo, 2021, skaitmeninè nuotrauka, $35 \times 25$, asmeninis archyvas

Vytautas Gečas, Untitled, 2021, digital photo, $35 \times 25$, courtesy of the artist. 
kad visi neatrinkti variantai išlieka ịsikūniję daikte. Bent jau jų potencialas. Galbūt tai profesinè liga arba kūrybinis iššūkis nuolat galvoti, kas galètų būti šis daiktas, jei jis nebūtų savimi? Kaip žmogus gali keisti savo kvalifikaciją arba tobulinti profesiją, taip gal gali ir daiktas? Neretai, tiesiog apvertus daiktą, nesunkiai formuojasi naujas hipotetinis pritaikymo kontekstas.

Esu linkęs manyti, kad kiekvienas daiktas iš esmès yra daugiafunkcis. Turiu omenyje ne tokius daiktus, kaip sofa-lova ar šveicariškas armijos peiliukas, kurie yra skirti labai konkrečiai vartoti. Dažnas bandymas praplèsti ar padidinti daikto vertę papildoma funkcija arba funkcijomis blankina daikto identitetą ir suprastina objektą abiejų funkcijų kontekste.

Kitokị daikto funkcinị įvairiapusiškumą galime lengvai įžvelgti buityje: kėdès atlošas tampa rūbų pakaba, stiklinè - vieta susidèti dantų šepetèlius, tuščia dèžè - vieta atsisėsti ${ }^{31}$ [2, 3 il.]. Specifinès situacijos ar poreikiai gali pasiūlyti naują funkcinį daikto potencialą ${ }^{32}$. Ir galimai ne tą, kurị buvo numatęs dizaineris. Mègstu sakyti, kad daiktai pradeda gyventi savo gyvenimą tada, kai jų kūrẻjo darbas būna baigtas. Kai daiktai atsiranda žmonių rankose, namuose ir gyvenimuose, susiformuoja ju galutinis pavidalas.

Galvojant apie tai, kaip stipriai gali pakisti daikto prasmė, galima prisiminti „VW Beetle“ istorija - kurtas nacistinès Vokietijos totalitarinio režimo visuomenei, jis tapo ikoniniu simboliu hipių kultūroje ${ }^{33}$ [4, 5 il.]. Taigi daiktai kuriami, perkami ir naudojami, bet kasdienybės praktikoje objektai tampa subjektais, kuriančiais savo individualią istoriją ${ }^{34}$. Taip teigdamas, nesiekiu poetiškai personifikuoti daiktų. Manau, kad daikto „asmenybės“ paieška ar identifikavimas yra procesas, atskleidžiantis sudètingą gamybos ir daikto vystymosi eigą. Tokiu būdu kvestionuojama žmogaus empatija daiktams vartojimo kontekste.

Taip, funkcija yra daikto esmè, bet ne jị apibrèžianti savybè. Projektuojant daiktą, neapsiribojama tik jam numatyta funkcija, bet apmąstomos ir gamybinès, ekonominès, estetinès daikto savybès. Dizaineris visada galvoja apie platesnị daikto veikimo lauką, o ne tik apie techniškai atliekamą

31 Michael Erlhoff ir Brandes Uta, Non Intentional Design (Cologne: Daab, 2006).

32 „Kroesas apibūdindamas, kaip susidaro funkcija, teigia, kad daikto techninè funkcija, nors ir tiesiogiai susieta su daikto fizinėmis savybėmis, dažnai yra priklausoma ir nuo žmogaus ketinimų." Malpass, Critical Design in Context: History, Theory, and Practices, 81.

33 Jonathan Glancey, The VW Beetle: How Hitler's idea became a design icon, 2014, https://www.bbc.com/culture/article/20130830-the-nazi-car-we-came-to-love.

34 „Daikto funkcija yra tiek fizinis, tiek socialinis konstruktas, o daikto naudojimas remiasi dualistinès ontologijos pagrindu." Malpass, Critical Design in Context: History, Theory, and Practices, 82. 


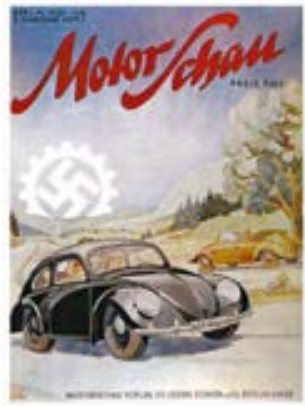

4.

Motor Schau žurnalo viršelis,

$1938 \mathrm{~m}$. liepos 2 d., $24 \times 32$

Motor Schau magazine cover,

July 2, 1938, $24 \times 32$

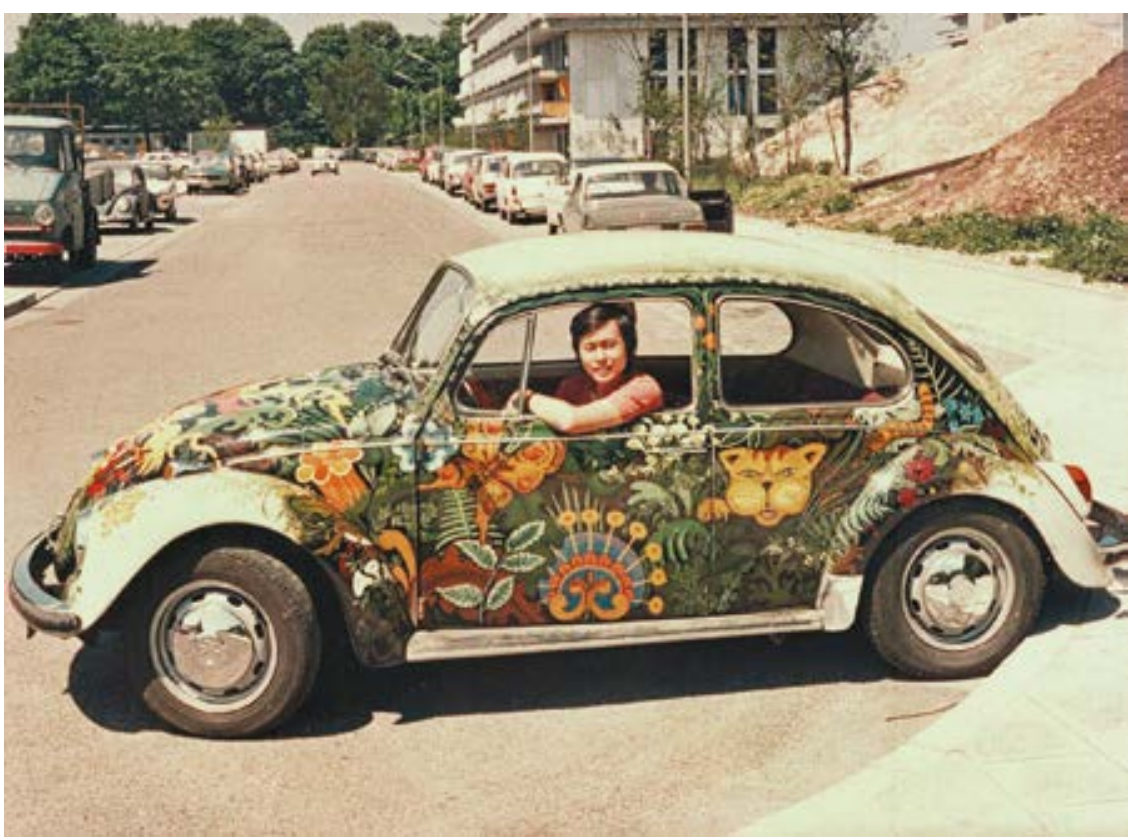

5.

Nežinomas autorius, Flower Beetle, 1960 m. pabaiga, $\quad$ Unknown artist, Flower Beetle, late 1960, $13 \times 10$ $13 \times 10$ 
jo funkciją. Jei ne sąmoningai, tai bent intuityviai. Funkcijos dualumas yra kintanti kontekstinè reikšmè, nes vartotojo rankose funkcija tampa jo intencijų reikalu ${ }^{35}$.

Industrinis dizainas yra orientuotas ị vartotoją, todèl jam būdingas tradicinis, utilitarus funkcijos suvokimas. Svarbiausia daikto verte išlieka jam priskirta funkcija, patenkinanti vartotojo poreikius, dèl kuriu jis ir nusprendžia daiktą ịsigyti. Kritinis dizainas yra ị patį dizainą orientuota praktika, kvestionuojanti ịsitvirtinusius dizaino principus, tarp jų ir funkcijos reikšmę ar išraišką̧ ${ }^{36}$. Taigi funkcijos arba daikto esmès suvokimas šiose srityse skiriasi. Tai atveria ịvairius būdus interpretuoti objektus ir jų veikimą, bet tuo pačiu didina atskirti tarp dviejų dizaino praktikų. Ypač kategoriškas šiuo požiūriu yra industrinis dizainas, kuriame konvencinis funkcijos suvokimas yra tapęs ir „gero“ dizaino vertinimo rodikliu" ${ }^{37}$. Dažnai kritinio dizaino kritika ir yra nukreipta ị objekto kaip masinei gamybai paruošto produkto vertę. Funkcija nèra išsamiai apibrěžianti daiktų savybè, todèl ir negali būti absoliučiu vertinimo kriterijumi:

sąvoka „funkcija“ yra dažnai vartojama kritinio dizaino praktikos kritikai pagrịsti ir apibendrintai įvardyti kritinio dizaino praktiką kaip konceptualaus meno formą. Diskusija rodo, kad „funkcija“ nèra pakankamas pagrindas kritikuoti ir kategorizuoti. Yra teigiama, kad kritinis dizainas nèra dizainas, nes objektai utilitarine prasme neveikia efektyviai. Funkcija, nagrinėjama kaip konceptas, atskleidžia, kad objekto funkcija prasiplečia už naudingumo, efektyvumo ir optimizavimo sąvokų, ir net griežčiausia modernistine sąvokos prasme funkcija visada sudarẻ savybes, kurios peržengia fizinio optimalumo ribas. ${ }^{38}$

35 „funkcija yra reliatyvi ir situacinė; tai yra dinamiška savybė, besiremianti subjektyvumu, bet ne nustatyta fiksuota tvarka." Ibid., 81.

36 „Robach teigia, kad kritinis dizainas peržengia disciplinos ribas, plečia sąmoningumą ir peržengia konvencinio produkto dizaino ribas. Provokatyvus kritinio dizaino vaidmuo atskleidžia išankstinius, suformuotus vartotojo ịpročius ir jų ribas paverčia nepastoviomis ir išblukusiomis. Savo komentare ji atkreipia dėmeși ị socialinės kritikos elementą kritiniame dizaine, tačiau teigia, kad „,̌i kritika nėra šališka, jei ji yra nukreipta ị tokias dideles socialines problemas kaip, pavyzdžiui, vartojimas ir gamyba (Robach 2005, 36).“ Ibid., 46.

37 „Antra, Moline'as identifikuoja, kaip kritinė meno praktika ir vizualioji kultūra dažnai gana siaurai suvokia funkcijos sampratą. Ši siaura samprata, apsiribojanti praktiniu funkcionalumu, pagrịstu optimizavimu ir efektyvumu, tampa viena svarbiausių kliūčiu vertinant kritinio dizaino praktiką pramoninio dizaino kontekste. Todèl norint plètoti kritinio dizaino praktiką, kaip dizaino profesijos sudedamają dali, reikia performuoti supratimą, kad funkcija apsiriboja praktiškumu, optimizavimu ar efektyvumu." Ibid., 78.

38 Ibid., 14. 
Grịždamas prie minties, kad daiktai savaime yra daugiafunkciai, manau, kad skirtingos daikto savybės ir vertės yra ir skirtingos daikto funkcijos. Larry L. Ligas daikto funkciją taip pat dekonstruoja i skirtingas savybes $^{39}$ :

- Struktūrinis artikuliavimas, nurodantis objekto materialinę struktūrą;

- Fizinė funkcija, nurodanti utilitarinę objekto užduoti;;

- Psichologinè funkcija, susijusi su vartotojo emociniu atsaku ị objektą;

- Socialinė funkcija, nurodanti objekto vykdomos veiklos pobūdị atsižvelgiant ị socialinę dimensiją;

- Kultūrinè-egzistencinè funkcija, pasižyminti gilesnėmis kultūrinėmis ir simbolinėmis savybėmis, kurios apima objektą naudojančio individo egzistencinę būtị.

Archeologai praeiti gali atkurti nagrinėdami rastus daiktus ir jų savybes. Šie daiktai jiems gali paaiškinti to meto žmonių ịpročius ir vertybes, idejjas. Tai ir šiandien yra neatsiejama daiktų savybė ir funkcija. Archeologè Michael Schiffer ${ }^{40}$ ją vadina ideofunkcija (ideo-function). Tai, kas Ligui yra struktūrinė ir fizinè funkcija, Schiffer įvardija technofunkcija (techno-function) - čia daikto fiziškumas yra suvokiamas per jam paskirtą funkciją. Paskutinioji jos ịvardijama yra sociofunkcija (socio-function), kuri, panašiai kaip ir Ligo, apibrèžta „socialinė funkcija“ veikia kaip materiali medija, komunikuojant platesniame socialiniame kontekste.

Skirtingos funkcijos traktuotès koreliuoja ir su Jeano Baudrillard'o suformuluota objekto verčių sistema ${ }^{41}$ :

- Funkcinè vertė: daikto instrumentinė paskirtis (naudojimo vertė). Pavyzdys: rašiklis rašo; šaldytuvas šaldo.

- Mainų vertè: daikto ekonominè vertè. Pavyzdys: vienas rašiklis gali būti vertas trijų pieštukų, o vienas šaldytuvas gali būti vertas trijų mẻnesių atlyginimo.

- Simbolinè vertè: daikto vertè, kurią subjektas priskiria kito subjekto atžvilgiu (t. y. tarp davejjo ir gavejjo). Pavyzdys: rašiklis gali simbolizuoti dovaną mokiniui mokyklos baigimo proga; piršlybu žiedas gali būti viešai paskelbtos santuokinès meilès simboliu.

39 Ibid., 79.

40 Ibid., 80.

41 Jean Baudrillard, For a Critique of the Political Economy of the Sign (London: Verso Books, 1983). 
- Ženklo vertė: daikto vertė daiktų sistemoje. Pavyzdys: tam tikras rašiklis, nors ir neturi jokios papildomos funkcinès naudos, gali reikšti prestižą kito rašiklio atžvilgiu; deimantinis žiedas neturi jokio praktinio panaudojimo, tačiau gali reprezentuoti tam tikras socialines vertybes, tokias kaip skonis ar socialinè klasė.

Kritinio dizaino praktika ne visada tiesiogiai, bet siekia kvestionuoti įvairias daikto vertes ir funkcijas. O kartais ieško naujų. Ir atranda, remdamasi eksperimentine praktika, priešinga industrinio dizaino metodams, kai jau nuo pradžių žinoma, koks bus rezultatas. Tačiau ir pati industrinio dizaino praktika, ịprastai suvokianti daiktą tik per jo fizinę išraišką, neretai peržengia fizinès daikto funkcijos ribas.

Industriniam dizainui būdinga funkcijos samprata susiformavo modernizmo laikais. Bauhauzo mokykloje išsirutulioję principai - stengtis optimizuoti visus tiek daikto kūrimo, tiek gamybos procesus - išliko ir šių dienų masinès gamybos poreikius atitinkančiu požiūriu ${ }^{42}$. Taip žvelgiant, praktinis daikto funkcionalumas priklauso ne tik nuo fizinės daikto funkcijos efektyvumo, bet ir nuo gamybos proceso, logistikos kaštų optimizavimo ir panašiai. Kitaip tariant, daikto funkcionalumą sudaro ir fizinės funkcijos, skirtos vartotojui, ir daikto praktiškumas, ji gaminant, arba efektyvumas, taupant vietą ji transportuojant ar sandèliuojant.

$\mathrm{O}$ ar daiktas neturi teisès egzistuoti be jam nustatytos diagnozès problemos? Ar daikto funkcija ir yra jo sprendžiama problema? Kada kèdè tampa „tik dar viena kėde“? Ar kiekvieną kartą problema turi būti dar nespręsta, norint pateisinti daiktą ir jo dizainą? Ar kiekviena dizaino raidoje išspręsta problema nėra kova su tuo metu įsitvirtinusiomis suvokimo ar naudojimo normomis? Ar naujo (gero) dizaino tikslas nèra iš principo keisti esamas normas?

Kritinio dizaino praktikos tikslas yra kvestionuoti norminius principus, technologijas ir metodus, o industrinio - juos taikyti. Todèl ir kalbama apie „taikomuosius“ menus. Industrinis dizainas pasirenka adaptuoti tai, kas tuo metu technologijose yra aktualiausia ar naujausia, kartu

42 Visi eksperimentavo su skirtingais problemų sprendimo metodais ir sisteminiu projektavimo metodu. Ulmo mokykla buvo įtakinga vokiečių dizaino mokykla, tęsusi modernistinius Bauhauzo idealus. Ulmo mokyklos taikyta praktika mokè, kad dizaino procesas turi būti optimizuojamas iki esminių aspektų, o ịprasminta funkcinė išraiška turètų išvalyti visuomenę nuo buržuazinio turinio, o daikto utilitarumas formuoti vartojimo ịpročius. " Malpass, Critical Design in Context: History, Theory, and Practices, 20. 
atliepdamas laikmečio tendencijas, suformuotas kultūrinių ịpročių, jam taip pat svarbi ekonominè vertè. Tai dizainas, patvirtinantis norminius principus (affirmative design) ${ }^{43}$, - iš galimų (turimų) resursų jis formuoja geriausia rezultatą. Kritiniame dizaine mąstoma kitaip:

Todèl kritinio dizaino praktikos ryšys su tradiciniu industriniu dizainu yra agonistinis, tai yra santykis paremtas diskusija, pliuralizmu ir savo pozicijos ginimu. Kai kritinis ir industrinis dizainas yra laikomi vienas kitą papildančiais laukais, konstruktyviai veikiančiais agonistiniuose santykiuose, kritinė projektavimo praktika papildo ir praplečia produkto dizaino discipliną. Kritinis dizainas skatina peržiūrèti nusistovejjusias normas, projektavimo procesus ir principus, o ne tik pasyviai priimti norminę praktiką ir hegemoniją. ${ }^{44}$

Analizuodamas dizaino lauko problematiką, kritinis dizainas gali pasirinkti atskirai nagrinėti tam tikrus dizaino ar daikto aspektus (gamybą, funkciją, estetiką ir t. t. ), tokiu būdu susiaurindamas savo veikimo lauką ir ji gilindamas. Galiausiai naujas kuriamas daiktas kritinio dizaino kontekste neretai yra veikiau priemonè ir ịrankis nagrinėti daiktiškąsias temas nei rezultatas - prekè ${ }^{45}$. Masinei gamybai tinkantys principai turi būti universalūs, nes turi atitikti daugelio poreikius. Tuo tarpu kritinis dizainas, veikdamas siauresniame kontekste, gali ieškoti specifinių sprendimų, kurie taikliau atskleidžia temą, bet tampa sunkiau suprantami, nes nèra dažnai sutinkami, priešingai - yra unikalūs, tikslingai formuojantys alternatyvius scenarijus esamoms, ịsitvirtinusioms situacijoms ${ }^{46}$. Taigi skirtingi kritinio ir industrinio dizaino metodai atspindi skirtingus šių sričių tikslus, nors ir yra

43 „Dizaino profesiją galima skirstyti ị dvi labai plačias kategorijas: norminius principus patvirtinantis dizainas (affirmative design) ir kritinis dizainas. Pirmasis sustiprina tai, kas yra dabar; jis atitinka kultūrinius, socialinius, techninius ir ekonominius lūkesčius. Didžioji kuriamo dizaino dalis patenka ị šią kategoriją. Antrasis atmeta tai, kad dabartis yra vienintelè galimybių skalè. Kritinis dizainas kvestionuoja vyraujančios situacijos principus pasitelkdamas dizainą ir ịkūnija alternatyvias socialines, kultūrines, technines ar ekonomines vertybes." Ibid., 46.

44 Ibid., 130.

45 „Jie siūlo dizaino praktiką, kuria siekiama ne realizuoti komercinės naudos siekiančius daiktus, bet kvestionuoti visuomenès suvokimą vartotojiškos kultūros kontekste ir santykị su daiktais. Užuot sutelkę dėmesị tik ị vartotojo poreikių tenkinimą, jie siūlo, kad daikto dizainas turi būti paremtas idèjiniu pagrindu, provokuojančiu mąstymą.“ Ibid., 31.

46 „Tačiau besitęsianti kritinio dizaino tradicija industrinio dizaino kontekste buvo atkurti alternatyvią nuomonę apie produkto dizainą, projektuojant daiktus, pasakojančius istorijas apie žmogaus vertybes ir elgesį, atgaivinti savybes, kurios buvo pamirštos kuriant komercini gaminio dizainą." Ibid., 38. 
glaudžiai susiję. Kritinės praktikos radikalumas gali trukdyti abiejų praktikų bendrumui, bet iš esmės jų abiejų tikslas yra papildyti, keisti, atskleisti dizainą ir jo potencialą ${ }^{47}$ :

Pramoninis dizainas turi iš naujo perinterpretuoti mechaninio ir elektroninio pasaulio išraišką ir vertybes. Taip yra ne tik todèl, kad naujos technologijos reikalauja platesnio ir abstraktesnio požiūrio, bet ir dèl to, kad iškyla tokių iššūkių nusistovėjusiai tvarkai kaip aplinkosauga ir geopolitiniai pokyčiai. Tam reikia iš naujo iqvertinti dizainą, gamybą ir rinkodarą visoje pramonès grandinëje. Todèl turime suteikti daugiau intelektualinès gilumos projektavimo patirčiai. Norėdama ịveikti ateities iššūkius, ši profesija turi atgauti savo tradicinę kultūrinę ir strateginę vertę. Reikalauti kultūros vertybių pavertimo šiuolaikinėmis idejjomis ir produktais. Nepakaks tik teikti kompetentingas technines arba problemų sprendimo paslaugas (Wiel 1994, 123). ${ }^{48}$

Industrinis dizainas savo taikomais metodais negali išspręsti kylančiu problemų, nes savo praktika tik papildo jų susidarymo priežastis. $\mathrm{O}$ kritinio dizaino praktika, veikdama prieš nusistovẻjusias dizaino konvencijas, skatina ị problemas pažvelgti kitaip:

Kritinio dizaino praktika siekia, kad vartotojai atsiribotų nuo ịprastų vartojimo būdụ. Kritinio dizaino tikslas - padaryti daiktus neatpažistamus ir keistus - leidžia mums pradèti galvoti apie tai, kaip galètume ịvairiai naudoti ir projektuoti objektus. Vartotojiškos visuomenès ịpročiu analizavimas tampa reikšmine praktikos savybe. Be to, atsiribojimas nuo konvencinès praktikos suteikia galimybę stebėti ir ịvertinti naujas vartotojų patirtis bei ịspūdžius ir paversti tai naujomis žiniomis. Dviprasmiškumas, kaip savybè ir atsiribojimas, kaip metodas, performuluoja praktiškumo ir efektyvumo sąvokas, bet ir sąlygotą rutiną verčia prasmingu žmogaus ir daikto santykiu. ${ }^{49}$

47 ,Taigi, kaip komercinio dizaino kontekste yra pabrèžtinai vertinamas daikto funkcinio ir gamybinio konteksto suvokimas, deramas pasirinktos spręsti probleminès situacijos identifikavimas ir analizavimas, o išvados paverčiamos gamybos ir vartotojo lūkesčius puoselèjančiu dizaino kūriniu, taip ir kritinio dizaino praktikos fundamentą sudaro iš esmès tų pačių principų puoselèjimas." Ibid., 129.

48 Ibid., 28.

49 Ibid., 63. 


\section{Daikto savirealizacija}

Man, kaip daiktų dizaineriui, svarbu, kur šioje kūrybos, gamybos, vartojimo grandinėje atsiduria pats daiktas. Kaip jis savo savybėmis gali keisti suvokimą apie save. I objektą orientuota ontologija ịvardija keletą daikto pozicijų ${ }^{50}$. Pirmoji yra fizinè - tai, iš ko daiktas yra padarytas, antroji - simbolinè, kaip individas jị suvokia, ir trečioji - daiktas pats savaime. Ši trečioji pozicija mane domina labiausiai, nes yra mažiausiai arba apskritai nenagrinèta dizaino kontekste ir dèl to, kad kitose dviejose dizaino problematika yra labai aiški. Tai pirmiausia fizinis daikto suvokimas arba daikto redukavimas iki to, iš ko jis yra pagamintas. Čia daiktas yra suvokiamas jo gamybos ir fizinės funkcijos kontekste. Simbolinis daikto suvokimas - daikto redukavimas iki to, kaip jis yra suvokiamas emociškai, arba iki daikto kuriamo efekto. Pirmuoju atveju visada bus rūpinamasi atlikti darbą kaip i̇manoma mažesniais kaštais, dažnai aukojant daikto kokybę, o antruoju bus mėginama formuoti dar neigytą santykị su daiktu, bet ne atsižvelgiant i tai, koks daiktas yra, bet koks aš galiu būti, ji ịsigijęs. Vienas byloja apie perteklinę gamybą, kitas - apie vartotojiškumą.

O kokia yra trečioji pozicija? Ji remiasi daikto autonomija - kai daiktas yra tiesiog tai, kas jis yra. Tai daikto emancipacija nuo įsitvirtinusių ar formuojamų išankstinių suvokimo normų. Arba daikto savirealizacija, kurią aš suvokiu kaip jo kūrimo procesą, atsižvelgiant i tai, kuo pats daiktas nori ar turi būti. Tai pozicija, atskleidžianti daikto potencialą per jo daiktiškąsias savybes ir funkciją, galvojant apie santyki su žmogumi, remiantis ergonomika, daikto veikimo aplinkos analize. Puoselėjant daikto „ego“, galima atskleisti jo potencialą - kaip jis gali geriausiai tenkinti žmogaus poreikius projektuojamoje naujoje situacijoje. Tai pastebimas ir ị save dèmesi atkreipiantis daiktas, savo daiktiškosiomis savybėmis nepaliekantis žiūrovo abejingo, kad būtų visavertiškai suvokiamas ir puoselejjamas.

50 „Mokslininkai redukuoja daikto suvokimą iki subatominių dalelių; humanitariniai mokslai redukuoja iki daikto efekto jo savininkui ir aplinkai. Tiesiai šviesiai tariant, abu Eddingtono daikto paaiškinimai yra visiška apgaulè, kurie painioja daiktą su jo vidinėmis ir išorinėmis savybèmis. Tikrasis stalas iš tikrujų yra trečiasis stalas, esantis tarp minètų dviejų. Ir jei abu (mokslinis ir humanitarinis) Eddingtono paaiškinimai suteikè moralinị pagrindą dviem Snow diskursams daikto nagrinèjimo kontekste, mūsų trečiajam būdui tikriausiai reikia trečiojo diskurso, visiškai kitokio nei šie du. Tai nereiškia, kad trečiasis diskursas yra visiškai naujas: galbūt tai yra meno kultūra, kuri, atrodo, sugeba kalbėti apie daiktą neredukuodama jo iki kvarkų ir elektronų arba stalo poveikio.“ Graham Harman, The Third Table: 100 Notes, 100 Thoughts: Documenta Series 085 (London: Hatje Cantz, 2012), 6. 


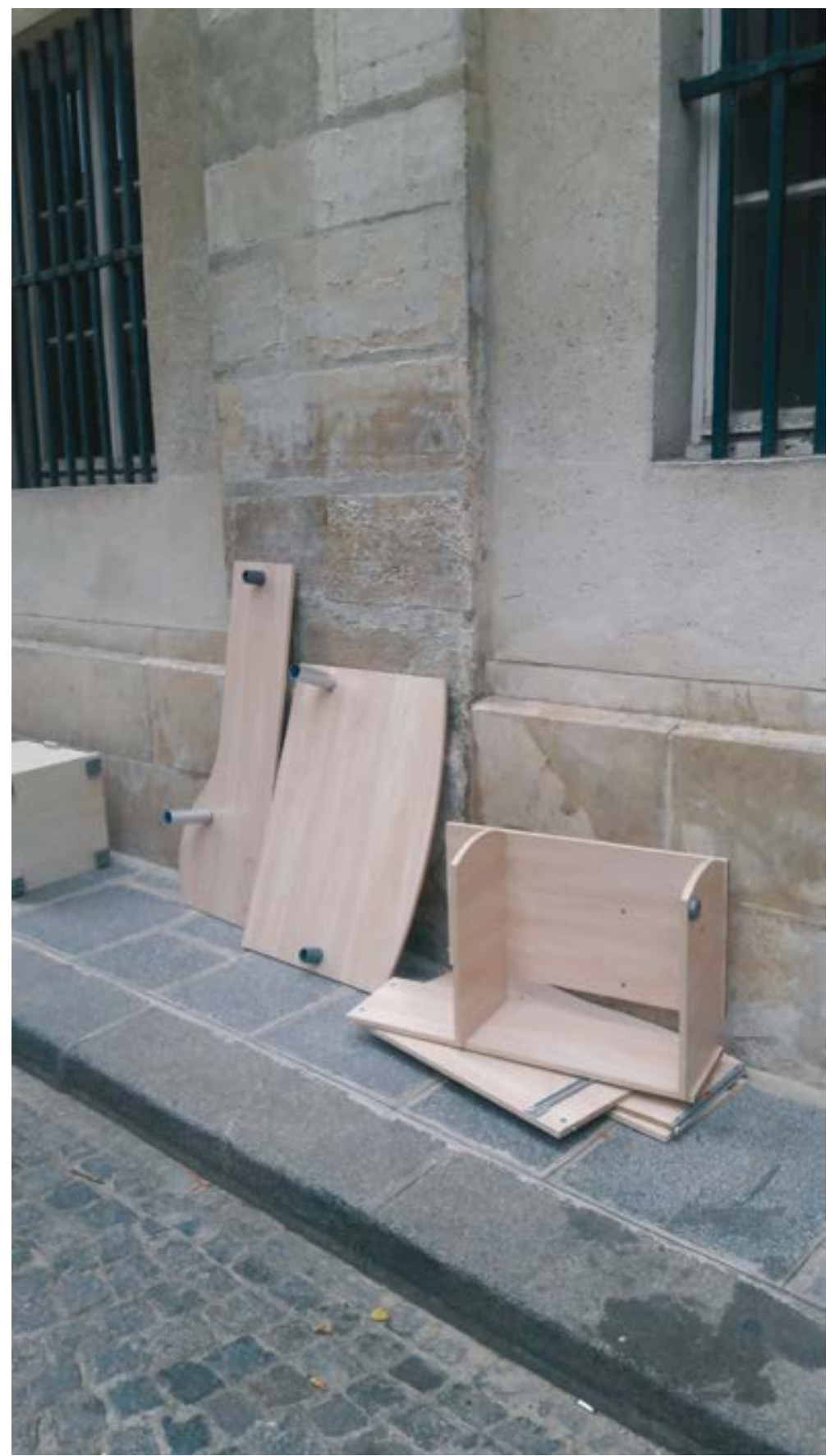

6.

Vytautas Gečas, Daiktų pasaulis, 2018, skaitmeninė nuotrauka, $20 \times 35$
Vytautas Gečas, The World of Objects, 2018, digital photo, $20 \times 35$ 


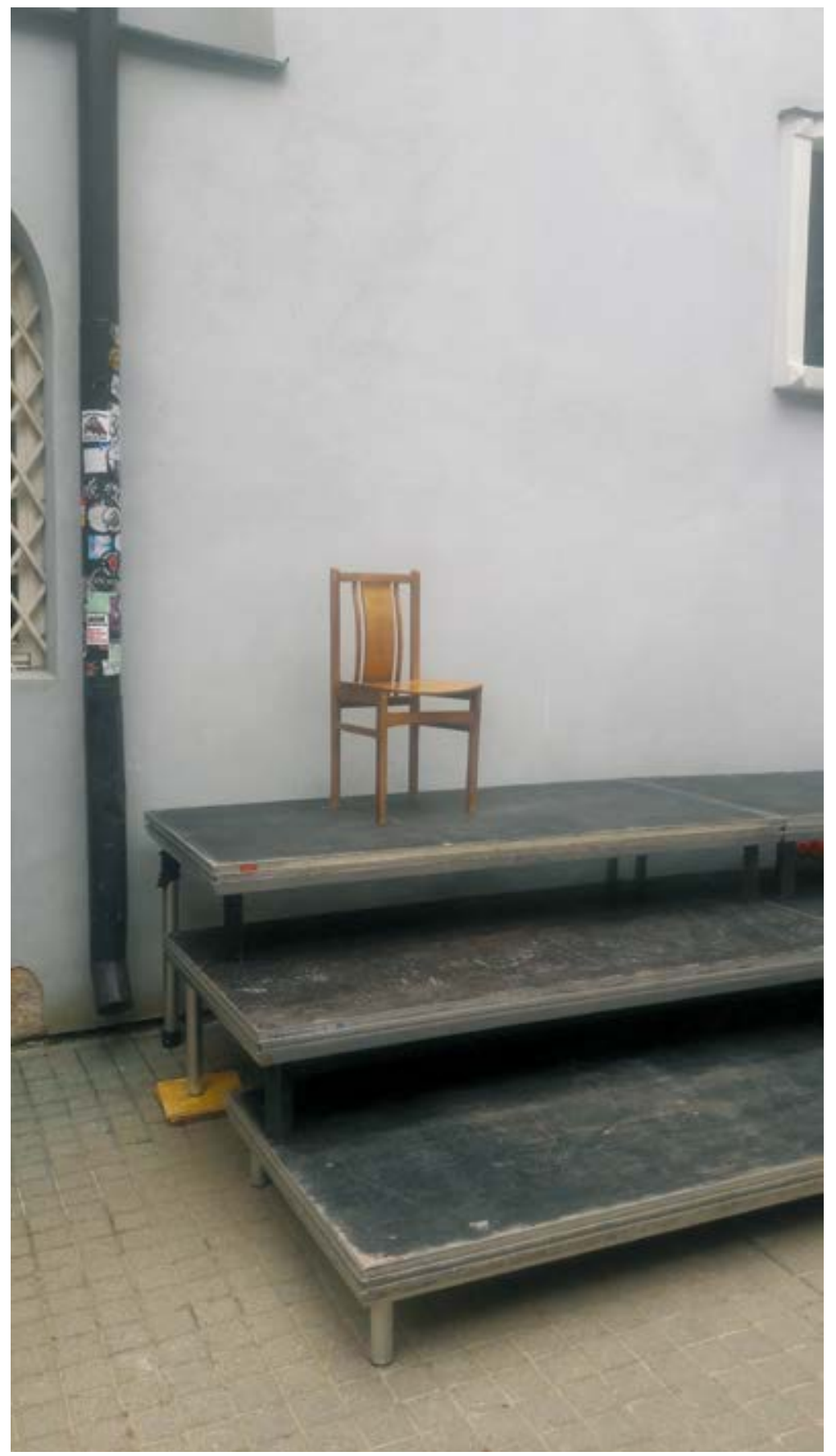

Vytautas Gečas, Daiktų pasaulis, 2019, skaitmeninė nuotrauka, $20 \times 35$
Vytautas Gečas, The World of Objects, 2019, digital photo, $20 \times 35$ 
Šis požiūris susiformuoja, kai sukaupiama pakankamai žinių, kaip daiktas yra ir gali būti gaminamas, kokios yra skirtingos medžiagų savybės ir kaip visa tai koreliuoja su daikto funkcija. Nors daiktai ir tarnauja mums, atlikdami jiems aiškiai paskirtą funkciją, aš mėgstu ịsivaizduoti, kad mes esame daiktų pasaulyje, o ne jie mūsų [6, 7 il.]. Kaip nuolat aplinką stebintis ir analizuojantis žmogus kreipiu dèmesi $i$ visus mane supančius daiktus - naują, seną, pigu, brangų, sulūžusị, veikiantị, gražų, nereikalingą, nepastebimą ir t. t. Esu pasirengęs iš jų mokytis ir atpažinti juose savo igytas žinias, bandydamas atskleisti jų atsiradimo istorijas ir priežastis. Klausiu, kaip standartizuota gamyba galèjo turèti ittakos daikto proporcijoms, medžiagu pasirinkimui, taip pat galimai daikto kainai, kokybei ar ilgaamžiškumui? Kaip išmatuojama daikto autoriaus subjektyvumo vertė? Buitis man yra inspiracijos šaltinis ir žmogaus sąveikos su daiktu stebėjimo laukas. Pavadinčiau tai profesine liga, virstančia žiniomis, tęstiniu tyrimu ir požiūriu, formuojančiu daiktų suvokimą, kurị imuosi perteikti kurdamas daiktus. Siekiu kiekviename daikte atskleisti tą dali industrinio dizaino matymo, kuris vis dar yra išlikęs sudètingas, net ir kalbant apie patị pigiausią ar paprasčiausią daiktą. Mąstant apie daiktą ir jo galimą atsiradimo istoriją, formuojasi objektyvus požiūris i jij, neredukuojant daikto ị tai, iš ko jis padarytas, arba iš anksto apibrěžiant santyki su juo. Vartojimo kontekste tai tampa nauju žiūrovo ir objekto santykiu, skatinančiu platesni daikto suvokimą ir didesni jo vertinimą, vedantị link daikto ilgaamžiškumo (mano hipotezè). Išaugęs sąmoningumas (increased awareness) ${ }^{51}$ galų gale veda link vartotojiškumo mažèjimo.

\section{Išvados}

Ar geras dizainas tiesiog tenkina fizinius žmogaus poreikius už kuo mažesnę kainą, ar jis remiasi dizainerio siekiu vis permąstyti mus supančius daiktus? Manau, kad iš principo ir industrinio, ir kritinio dizaino praktikos kritiškai, nors ir skirtingai, reaguoja ị aplinką ir jos veiksnius, o dizainerio vaidmuo neapsiriboja tik daiktų kūrimu, bet grindžiamas ir aplinkos, kurioje daikto poreikis susiformuoja, stebėjimu. Norint ịprasminti daiktų atsiradimą ir konkuruoti išpuoselètame komerciniame kontekste, daiktas savyje

51 „Tai apima bandymus reflektuoti ir ironizuoti, naudoti neịprastas medžiagas ir alternatyvius daiktų vartojimo scenarijus, siekiant geriau suvokti kasdienius daiktus, jų vartojimo poveikị ir įtaką pasauliui. Taip pasitelkiant daiktų dizainą kaip diskusijos priemonę. " Malpass, Critical Design in Context: History, Theory, and Practices, 28. 
turi turèti virsmo (kaitos) elementą, kuris tampa tiek pridètine verte ekonominiame kontekste, tiek aplinkybe, formuojančia platesnị daikto potencialą.

Analizuojant abi dizaino sritis, matyti, kad šios praktikos remiasi panašiais principais. Tačiau skirtingi tikslai koreguoja pasirenkamas priemones. Tikslas taikyti ir tikslas kvestionuoti dizaino metodus diktuoja ir skirtingą požiūrị, ir skirtingus metodus. Dualistinè daikto funkcijos ontologija veikia ir dizaino praktiką - dizaino vaidmuo gali būti pasyvus arba aktyvus, ittakos mastelis globalus arba intymus, kūrybinis procesas objektyvus arba subjektyvus, kuriama siekiant spręsti arba klausti, galutinis variantas ir sprendimas gali būti universalus arba individualus. Dvi dizaino sritys skirtingai ịvertina, kas yra svarbiau, tačiau abi ịsikūnija vienoje dizaino profesijoje.

Dizainas įsiskverbia ị visus gyvenimo aspektus. Taigi profesijos savirefleksija tampa ypač aktuali vis didejjančios ittakos fone. Formuojasi ir keičiasi ne tik vartojimo ịpročiai, technologinès galimybès, bet ir abipusè vartotojo ir dizainerio atsakomybė. Sąmoningumas, suvokimas, kad daiktas yra kažkas daugiau nei jo fizinè išraiška, tampa reikšmingu leitmotyvu tiek kūrybiniame, tiek vartojimo procese.

Žinoma, galima paklausti, ar mano siekis kurti konceptualius daiktus nèra tiesiog dizaino kūrèjo, autoriaus saviraiška? Suprantu, kad daiktu kūrybos procese noriu daugiau laisvės, teisės ị subjektyvų požiūrị, ką ir vadinu pridètine daikto verte. Siekdamas jos, industrinis dizainas taiko standartizuotus sprendimus, lemiančius komercinio produkto sėkmę. Tačiau man individualizuota patirtis atrodo vertingesnè nei universali ir standartizuota.

Industrinio dizaino maniera yra bandyti išspręsti iškeltą problemą vienu sprendimu. Tokia praktika dažnai maskuoja pačios problematikos kompleksiškumą ir galimą daikto potencialą. Pateikiant objektą kaip mūsų asmeninio komforto kūrèją, bet ne didesnės globalios sistemos dalị. Manau, norint keisti daikto suvokimą, jo daromą ittaką, reikia būti iškalbingesniems apie daiktą ir jo kontekstą. Daikto fizinejje išraiškoje turi atsispindèti priežastys, kodèl daiktas yra toks, koks jis yra. Galima atskleisti jo gamybinị procesą arba autoriaus idèją pasitelkus daiktiškąsias savybes. Kelti sau tikslą, kad daiktas, užduodamas apie save klausimus, skatintų žmogaus suvokimą. Šiuolaikinio dizaino objektas turi būti pastebimas. Dizainas turi

$103-2021$

Acta Academiae Artium Vilnensis 
būti iškalbingesnis, o ne slèpti jị lydinčius procesus. $\mathrm{O}$ šiuolaikinis dizaineris turi ne tik kurti daiktus, bet ir apie juos komunikuoti. Tiek tiesiogine prasme, tiek perkeltine itterpdamas daikto istoriją i ji patį.

Šis tyrimas yra ịrankis, padedantis atskleisti ne tik temą, bet ir mano, kaip dizainerio, pozicijos trapumą. Dviejų dizaino laukų (industrinio ir kritinio) trintis tampa atspirties tašku, nagrinėjant dizaino ir žmogaus santykius, klausiant, kokị vaidmenį atlieka ir kokią vertę jų kontekste turi daiktas, ar galimas daikto autonomiškumas, ar įmanoma kūryba, atsiribojanti nuo komercinio konteksto suformuluotų vartojimo ịpročių, gamybos normų, kaip būdas keisti, naujai formuoti, praplèsti daiktų suvokimą ir jų vertę.

Gauta 20210316 


\section{Literatūra}

Baudrillard, Jean. For a Critique of the Political Economy of the Sign. London: Verso Books, 1983.

Clark, Gregory. A Farewell to Alms: A Brief Economic History of the World. New Jersey: Princeton University Press, 2009.

Erlhoff, Michael and Uta Brandes. Non Intentional Design. Cologne: Daab, 2006.

Flusser, Vilem. The Shape of Things, A philosophy of Design. London: Reaktion Books, 1999.

Harman, Graham. The Third Table: 100 Notes, 100 Thoughts: Documenta Series 085. London: Hatje Cantz, 2012.

Jongerius, Hella and Louise Schouwenberg. Beyond the New Manifesto. dezeen.com, 2015.

Malpass, Matt. Critical Design in Context: History, Theory, and Practices. New York: Bloomsbury Publishing, 2017.

Michelkevičius, Vytautas. Meninio tyrimo suvesti. Žinojimo kontūras. Vilnius: Vilniaus dailès akademijos leidykla, 2016.

Tharp, Bruce M. and Stephanie M. Tharp. Discursive Design: Critical, Speculative, and Alternative Things. Cambridge, Massachusetts: MIT press, 2019. 


\title{
Summary
}

\section{Between Critical and Industrial Design. A Designer's View}

\author{
Vytautas Gečas
}

Keywords: critical design, industrial design, contemporary design, function, consumerism.

The text discusses industrial and critical design, the points of their intersection and separation. These two fields of design basically cover the same context of building things, but they play different roles. Supplementing one another, in contemporary design they become two sides representing different value orientations. Due to different design methods applied, they often become closed in their specific practices. The creative methods of critical design often correlate with the contemporary art field. Without taking it into account, it is difficult to interpret new methods in the framework of traditional design. In the meantime, industrial design practice most often meets the needs of the commercial market or production capacities, but not necessarily those of design itself or the consumer. This article analyses how these practices were formed historically, how they are different, and how they are interrelated.

Does good design merely satisfy the physical needs of an individual for a lesser price, is it based on a designer's aim to rethink the surrounding objects over and over again? In my opinion, generally speaking, both industrial and critical design practices critically, though differently, respond to the environment and its factors, and the designer's role is not limited to the design of objects, but is also based on the observation of the environment which produces the need for a new object. In order to justify the appearance of new objects and to compete in the highly-developed commercial context, an object must contain an element of transformation/change, which becomes both an added value in the economic context, and a circumstance creating a wider potential of that object. 